Prepared in cooperation with the Bureau of Reclamation Evaporation from Lake Mead, Arizona and Nevada, 1997-99

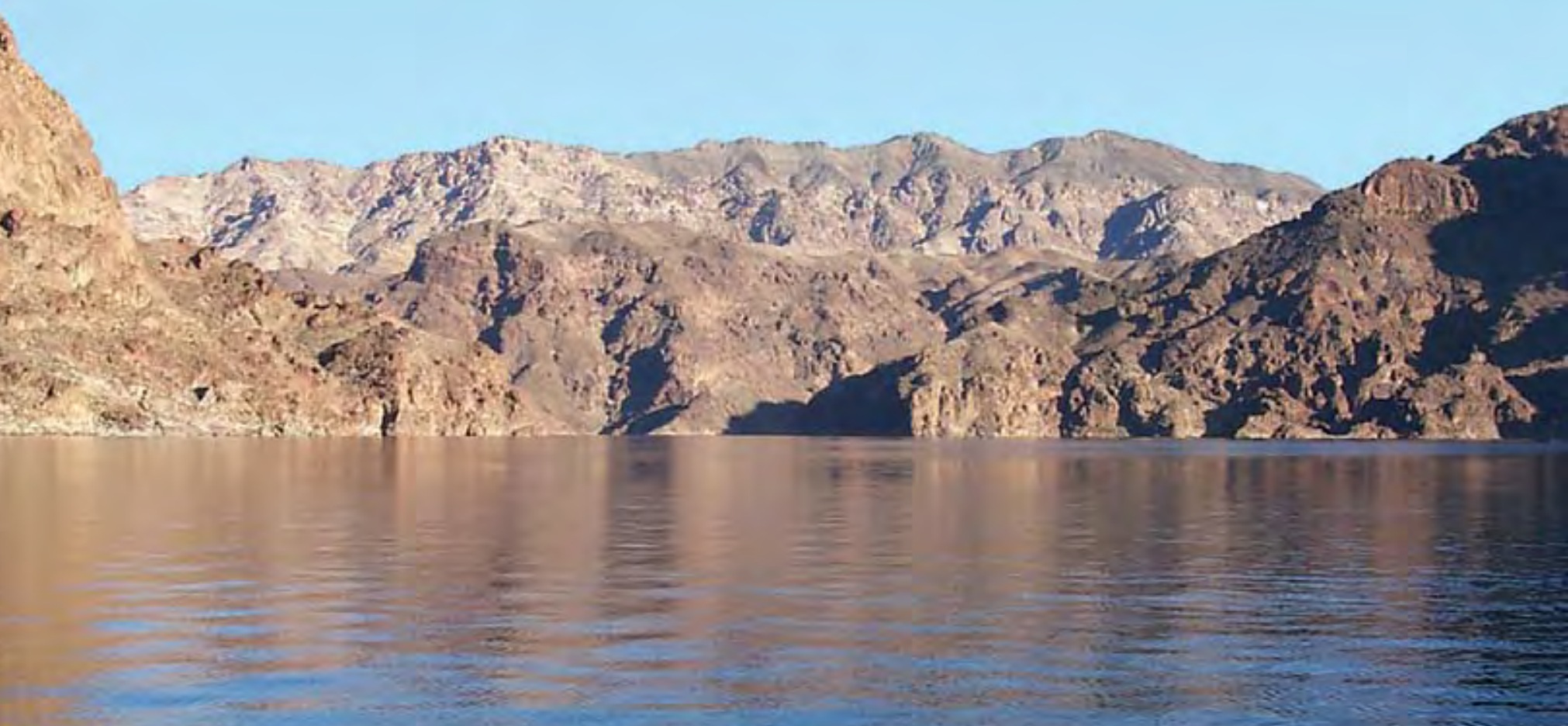

Scientific Investigations Report 2006-5252

U.S. Department of the Interior

U.S. Geological Survey 
Cover: Photograph of Lake Mead, Arizona-Nevada, looking east from Boulder Basin.

(Photograph taken by Craig L. Westenburg, U.S. Geolological Survey, March 31, 1998) 


\section{Evaporation from Lake Mead, Arizona and Nevada, 1997-99}

By Craig L. Westenburg, Guy A. DeMeo, and Daron J. Tanko

Prepared in cooperation with the Bureau of Reclamation

Scientific Investigations Report 2006-5252 


\section{U.S. Department of the Interior DIRK KEMPTHORNE, Secretary}

\section{U.S. Geological Survey \\ Mark D. Myers, Director}

\section{U.S. Geological Survey, Reston, Virginia: 2006}

For product and ordering information:

World Wide Web: http://www.usgs.gov/pubprod

Telephone: 1-888-ASK-USGS

For more information on the USGS--the Federal source for science about the Earth, its natural and living resources, natural hazards, and the environment:

World Wide Web: http://www.usgs.gov

Telephone: 1-888-ASK-USGS

Any use of trade, product, or firm names is for descriptive purposes only and does not imply endorsement by the U.S. Government.

Although this report is in the public domain, permission must be secured from the individual copyright owners to reproduce any copyrighted materials contained within this report.

Suggested citation:

Westenburg, C.L., DeMeo G.A., and Tanko, D.J., 2006, Evaporation from Lake Mead, Arizona and Nevada, 1997-99: U.S. Geological Survey Scientific Investigations Report 2006-5252, 24 p. 


\section{Contents}

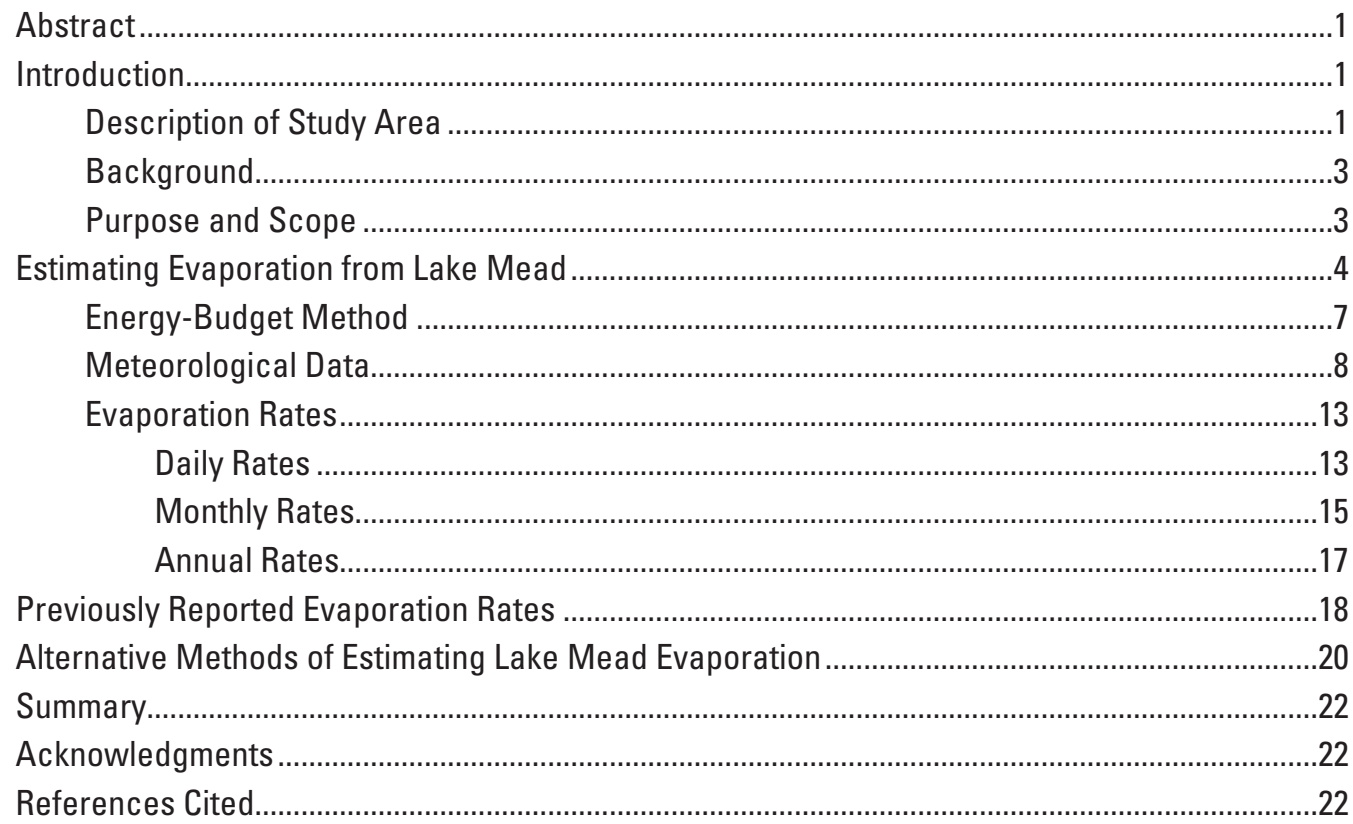

\section{Figures}

Figure 1. Map showing location of study area and evaporation stations, Lake Mead,

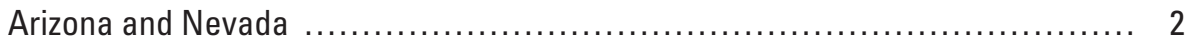

Figure 2. Photographs of four floating platforms on Lake Mead $\ldots \ldots \ldots \ldots \ldots \ldots \ldots \ldots \ldots \ldots$

Figure 3. Graph showing Lake Mead daily water-level elevation and date of station installation, February 1997-December 1999

Figure 4. Schematic of instrument configuration on floating platforms on Lake Mead, Arizona and Nevada, and of energy fluxes at water surface $\ldots \ldots \ldots \ldots \ldots \ldots \ldots \ldots$

Figure 5. Graphs showing air temperature, water temperature, and relative humidity collected at four floating instrumented platforms on Lake Mead, Arizona and Nevada, 1999

Figure 6. Graphs showing air temperature, water temperature, and relative humidity collected at the Sentinel Island evaporation station, Nevada, 1997-99.

Figure 7. Graph showing wind speed and direction at four floating instrumented platforms on Lake Mead, Arizona and Nevada, 1999

Figure 8. Graphs showing daily evaporation rates at four floating instrumented platforms at Lake Mead, Arizona and Nevada, 1999

Figure 9. Graphs showing total and average monthly evaporation at three floating instrumented platforms on Lake Mead, Arizona and Nevada, 1997-99 


\section{Figures-Continued}

Figure 10. Graphs showing comparison of total monthly evaporation at four evaporation stations with average monthly evaporation at all stations and three open-water evaporation stations with average monthly evaporation at

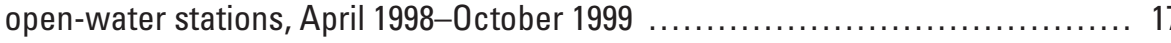

Figure 11. Graph showing annual Lake Mead evaporation, 1953-94 .................... 18

Figure 12. Box plot showing regression of monthly average net radiation at the Water Barge Cove station and total monthly evaporation at Sentinel Island station for: January through May 1997-99 and June through December 1997-99

Figure 13. Graph showing total monthly evaporation (average of open-water stations) and total monthly evaporation computed from monthly average net radiation at the Water Barge Cove station

Figure 14. Graph showing comparison of total monthly evaporation (average of open-water stations) and monthly evaporation computed from monthly mean net radiation at the Water Barge Cove station

\section{Tables}

Table 1. Average maximum and average minimum air temperature and average annual precipitation at Las Vegas and Overton, Nevada, 1961-90

Table 2. Site information for four floating instrumented platforms used to collect data to compute evaporation from Lake Mead, Arizona and Nevada, 1997-99

Table 3. Description of data, collected at four floating instrumented platforms, used to compute evaporation from Lake Mead, Arizona and Nevada, 1997-99

Table 4. Number of months with complete data, collected at four floating instrumented platforms, used to compute evaporation from Lake Mead, Arizona and Nevada, 1997-99

Table 5. Monthly mean meteorological and water-temperature data measured at four floating instrumented platforms on Lake Mead, Arizona and Nevada, 1997-99 _.. 9

Table 6. Total and average monthly evaporation from Lake Mead at four floating instrumented platforms, Arizona and Nevada, 1997-99.

Table 7. Average monthly evaporation and computed monthly evaporative loss from Lake Mead, Arizona and Nevada, July 1997-December 1999

Table 8. Total monthly, total annual, and average monthly Lake Mead evaporation, 1953-95 


\section{Conversion Factors, Datums, and Acronyms and Symbols}

Conversion Factors

\begin{tabular}{|c|c|c|}
\hline Multiply & By & To obtain \\
\hline \multicolumn{3}{|c|}{ Length } \\
\hline inch (in.) & 2.54 & centimeter $(\mathrm{cm})$ \\
\hline inch (in.) & 25.4 & millimeter $(\mathrm{mm})$ \\
\hline foot $(\mathrm{ft})$ & 0.3048 & meter $(\mathrm{m})$ \\
\hline mile (mi) & 1.609 & kilometer (km) \\
\hline \multicolumn{3}{|c|}{ Area } \\
\hline acre & 4,047 & square meter $\left(\mathrm{m}^{2}\right)$ \\
\hline acre & 0.4047 & hectare (ha) \\
\hline acre & 0.4047 & square hectometer $\left(\mathrm{hm}^{2}\right)$ \\
\hline acre & 0.004047 & square kilometer $\left(\mathrm{km}^{2}\right)$ \\
\hline square foot $\left(\mathrm{ft}^{2}\right)$ & 929.0 & square centimeter $\left(\mathrm{cm}^{2}\right)$ \\
\hline square foot $\left(\mathrm{ft}^{2}\right)$ & 0.09290 & square meter $\left(\mathrm{m}^{2}\right)$ \\
\hline square mile $\left(\mathrm{mi}^{2}\right)$ & 259.0 & hectare (ha) \\
\hline square mile $\left(\mathrm{mi}^{2}\right)$ & 2.590 & square kilometer $\left(\mathrm{km}^{2}\right)$ \\
\hline \multicolumn{3}{|c|}{ Volume } \\
\hline acre-foot (acre-ft) & 1,233 & cubic meter $\left(\mathrm{m}^{3}\right)$ \\
\hline acre-foot (acre-ft) & 0.001233 & cubic hectometer $\left(\mathrm{hm}^{3}\right)$ \\
\hline \multicolumn{3}{|c|}{ Flow rate } \\
\hline inch per day (in/day) & 25.4 & millimeter per day \\
\hline acre-foot per year (acre-ft/yr) & 1,233 & cubic meter per year $\left(\mathrm{m}^{3} / \mathrm{yr}\right)$ \\
\hline acre-foot per year (acre-ft/yr) & 0.001233 & cubic hectometer per year $\left(\mathrm{hm}^{3} / \mathrm{yr}\right)$ \\
\hline foot per year (ft/yr) & 0.3048 & meter per year (m/yr) \\
\hline miles per hour (mi/hr) & 0.447 & meters per second \\
\hline Knot & 1.609 & kilometer per day \\
\hline \multicolumn{3}{|c|}{ Energy flux } \\
\hline Watts per square foot $\left(\mathrm{W} / \mathrm{ft}^{2}\right)$ & 10.7643 & Watts per square meter \\
\hline \multicolumn{3}{|c|}{ Pressure } \\
\hline atmosphere, standard (atm) & 101.3 & kilopascal (kPa) \\
\hline Bar & 100 & kilopascal (kPa) \\
\hline
\end{tabular}

Temperature in degrees Celsius $\left({ }^{\circ} \mathrm{C}\right)$ may be converted to degrees Fahrenheit $\left({ }^{\circ} \mathrm{F}\right)$ as follows:

$$
{ }^{\circ} \mathrm{F}=\left(1.8 x^{\circ} \mathrm{C}\right)+32
$$

Temperature in degrees Fahrenheit $\left({ }^{\circ} \mathrm{F}\right)$ may be converted to degrees Celsius $\left({ }^{\circ} \mathrm{C}\right)$ as follows:

$$
{ }^{\circ} \mathrm{C}=\left({ }^{\circ} \mathrm{F}-32\right) / 1.8
$$


Datums

Vertical coordinate information is referenced to the U.S. Geological Survey datum, adjustment of 1912, locally known as "Power House Datum." Add 0.55 foot to convert to datum of 1929, leveling of 1935. Add 0.43 foot to convert to datum of 1929 , leveling of 1940 . Add 0.40 foot to convert to datum of 1929, leveling of 1948. Add 0.03 foot to convert to datum of 1929, leveling of 1963. No elevations have been converted to datum of 1929. Datum of 1929 is known as National Geodetic Vertical Datum of 1929 (NVGD of 1929) and was formerly called "Sea-Level Datum of 1929."

Horizontal coordinate information is referenced to the North American Datum of 1983 (NAD 83).

Altitude, as used in this report, refers to distance above the vertical datum.

Acronyms and Symbols

\begin{tabular}{ll}
\hline & Meaning \\
\hline$\gamma$ & empirical constant (equation 2) \\
$\rho$ & density of evaporated water (equations 1,3) \\
$\gamma_{c}$ & psychrometric constant (equation 3) \\
$E$ & evaporation rate (equations 1, 3) \\
$e_{0}$ & vapor pressure of saturated air at temperature of the water surface (equations 2, 3) \\
$e_{a}$ & vapor pressure of the air above the water surface (equations 2, 3) \\
$L$ & latent heat of vaporization (equations 1, 3) \\
$P$ & atmospheric pressure (equation 2) \\
$Q_{\theta}$ & change in energy stored in a body of water (equations 1,3) \\
$Q_{v}$ & net energy advected into a body of water (equation 1) \\
$Q_{b}$ & net energy lost by the body of water through the exchange of long wave radiation \\
$Q_{n}$ & $\quad$ between the atmosphere and the body of water (equation 1) \\
$Q_{r}$ & reflected solar radiation (equation 1) \\
$Q_{s}$ & solar radiation incident to the water surface (equation 1) \\
$R$ & Bowen ratio (equations 1, 2) \\
$R_{n}$ & monthly net radiation at Water Barge Cove \\
$T_{0}$ & temperature of water (equations 2,3) \\
$T_{a}$ & temperature of the air (equations 2, 3) \\
USGS & United States Geological Survey \\
\hline
\end{tabular}




\title{
Evaporation from Lake Mead, Arizona and Nevada, 1997-99
}

\author{
By Craig L. Westenburg, Guy A. DeMeo, and Daron J. Tanko
}

\begin{abstract}
Lake Mead is one of a series of large Colorado River reservoirs operated and maintained by the Bureau of Reclamation. The Colorado River system of reservoirs and diversions is an important source of water for millions of people in seven Western States and Mexico. The U.S. Geological Survey, in cooperation with the Bureau of Reclamation, conducted a study from 1997 to 1999 to estimate evaporation from Lake Mead. For this study, micrometeorological and hydrologic data were collected continually from instrumented platforms deployed at four locations on the lake, open-water areas of Boulder Basin, Virgin Basin, and Overton Arm and a protected cove in Boulder Basin. Data collected at the platforms were used to estimate Lake Mead evaporation by solving an energybudget equation. The average annual evaporation rate at open-water stations from January 1998 to December 1999 was 7.5 feet. Because the spatial variation of monthly and annual evaporation rates was minimal for the open-water stations, a single open-water station in Boulder Basin would provide data that are adequate to estimate evaporation from Lake Mead.
\end{abstract}

\section{Introduction}

\section{Description of Study Area}

Lake Mead is the largest reservoir by volume in the United States and was formed when Hoover Dam was completed in 1935 (fig. 1). It took until July 1941 for water to fill Lake Mead, which has a maximum surface elevation of 1,229 ft, a maximum surface area of 162,700 acres, and a maximum available capacity of 27,377,000 acre-ft (Bureau of Reclamation, 1967). At the maximum elevation of $1,229 \mathrm{ft}$ Lake Mead extends 65.9 mi upstream of Hoover Dam and has a maximum width of 9.3 mi (LaBounty and Horn, 1997, p. 95). The average lake elevation from 1942 (first complete calendar year of full pool) to 1995, based on monthly end-ofmonth elevations, is $1,169.9 \mathrm{ft}$ (retrieved at URL: http://www. usbr.gov/lc/riverops.html), which corresponds to a lake surface area of 125,600 acres.

The drainage area of Lake Mead at Hoover Dam is about 171,700 $\mathrm{mi}^{2}$ (Tadayon and others, 2000, p. 90). Ninety-seven percent of the inflow into Lake Mead is from the Colorado River (13.12 million acre-ft/yr, Tadayon and others, 2000, p. 80) with the remaining 3 percent from the combined flow of Las Vegas Wash (148,000 acre-ft/yr; Jones and others, 2000, p. 94), Muddy River (11,700 acre-ft/yr; Jones and others, 2000, p. 55), Virgin River (176,000 acreft/yr; Jones and others, 2000, p. 55), and ephemeral streams. The average annual release from Hoover Dam from 1935 to 1999 was about 10.1 million acre-ft (Tadayon and others, 2000, p. 99). Flow of the Colorado River at Diamond Creek (130 mi upstream of Hoover Dam) in calendar year 1999 was 12.69 million acre-ft, while the release from Hoover Dam was 11.04 million acre-ft (Tadayon and others, 2001, p. 110 and 128). Retention time for Lake Mead averages 3.9 years, depending on release and flow patterns.

Lake Mead is in an environment with a warm, arid climate. From 1961 to 1990, the average maximum air temperature was $105.9^{\circ} \mathrm{F}$ for Las Vegas, Nev., and $107.8^{\circ} \mathrm{F}$ for Overton, Nev. (fig. 1), whereas the average minimum air temperature was $33.6^{\circ} \mathrm{F}$ and $28.0^{\circ} \mathrm{F}$, respectively (table 1$)$. Average annual precipitation (1961-90) was 4.13 in. for Las Vegas and 3.31 in. for Overton (table 1). This warm, arid environment is conducive for high rates of evaporation. Sparsely vegetated, gentle to moderately sloping alluvial fans and steep, barren, rocky cliffs surround the lake. Generally, the adjacent hills rise to low or moderate height above the lake surface. The vast majority of lake is exposed to winds from the southwest to southeast. 

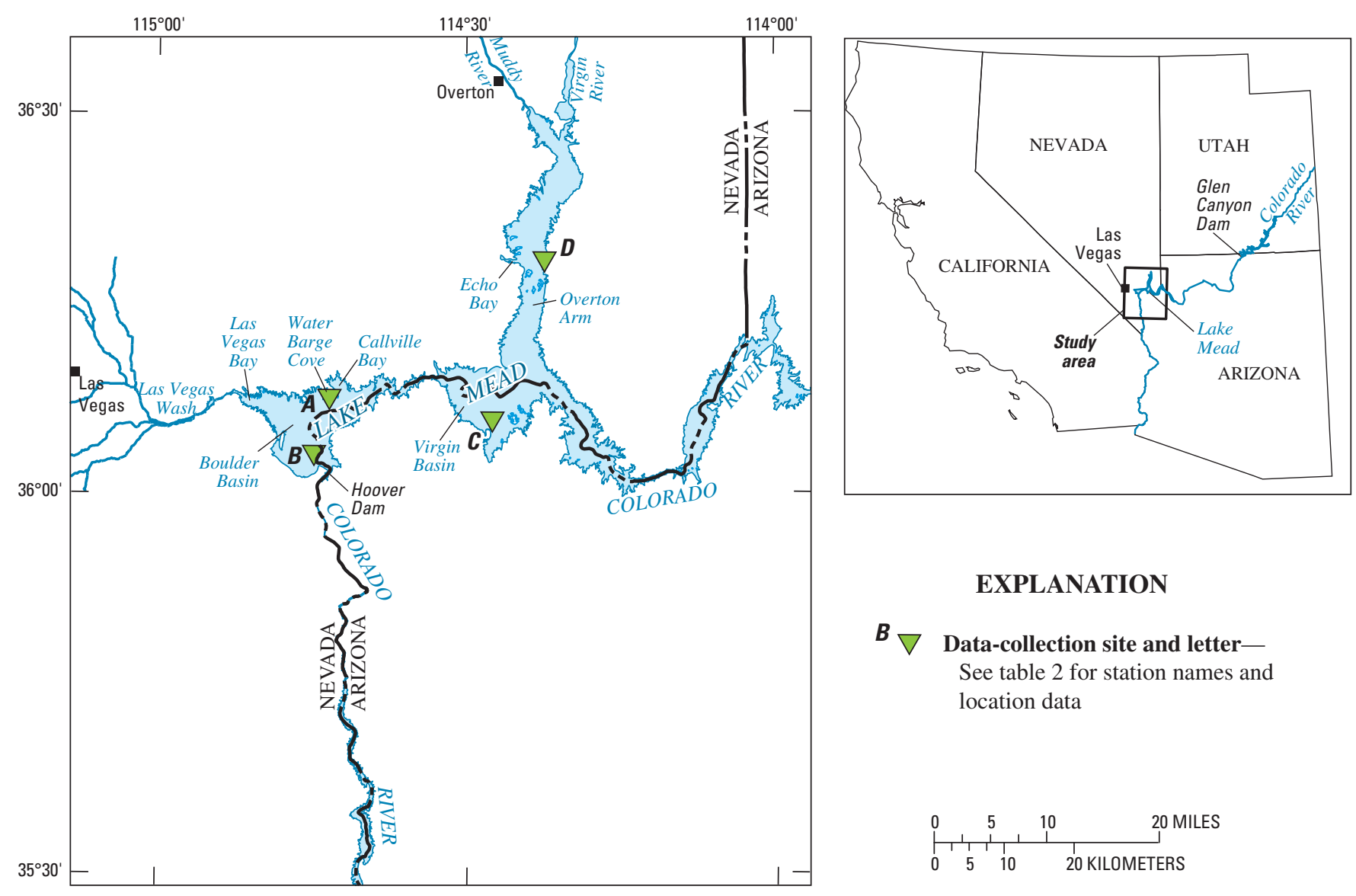

\section{EXPLANATION}

${ }^{B} \nabla$ Data-collection site and letter-

See table 2 for station names and location data

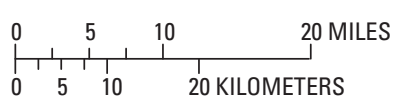

Base from U.S. Geological Survey digital data 1:100,000 scale, 1987:

Universal Transverse Mercator Projection, Zone 11

Figure 1. Location of study area and evaporation stations, Lake Mead, Arizona and Nevada.

Table 1. Average maximum and average minimum air temperature and average annual precipitation at Las Vegas and Overton, Nevada, 1961-90.

[Data for Las Vegas and Overton obtained from Desert Research Institute at www.wrcc.dri.edu. The period 1961-90 was selected because it coincides with official National Climatic Data Center records for Las Vegas. The 1961-90 data for Overton are unofficial]

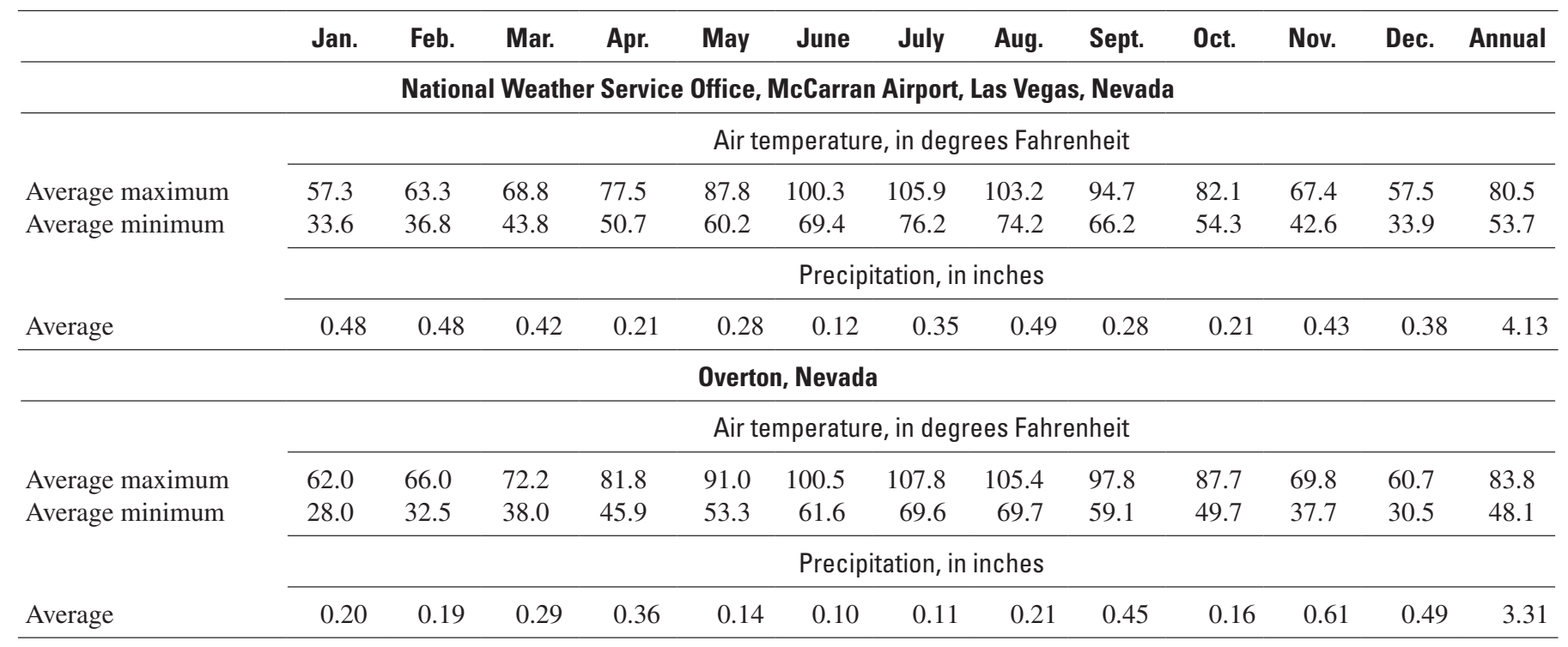




\section{Background}

Lake Mead is one of a series of large Colorado River reservoirs operated and maintained by the Bureau of Reclamation. The Colorado River system of reservoirs and diversions is an important source of water for millions of people in seven Western States and Mexico. The series of reservoirs along the Colorado River ensures a reliable supply of water for municipal and agricultural uses; allows for the generation of hydroelectric power; reduces the occurrence of uncontrolled floods within the basin; provides ecological habitat for numerous aquatic, riparian, and avian species; and provides a source of water-based recreation for millions of people.

The demand for Colorado River water has increased greatly as the population of the Southwestern United States has grown and as the maintenance and the development of ecological habitats has become a priority. Recent (2000) estimates of demand for Colorado River water in the Lower Colorado River Basin (parts of Utah, Arizona, Nevada, and California) are for irrigation of 2.7 million acres of land and municipal supply for 18 million people (Paul Matuska, Bureau of Reclamation, Lower Colorado River Regional Office, written commun., 2000). In contrast, Stanley (1960, p. 84) estimated that in 1949 Colorado River water was used to irrigate 500,000 acres of crops in Arizona and California and 300,000 acres of crops in Mexico and was used as municipal supply for 3.5 million people in California. Bureau of Reclamation (2000, p. 1) reported that in 1999 a total 10.95 million acre-ft of Colorado River water was used by the lower basin States (7.98 million acre-ft) and Mexico (2.97 million acre-ft).

Accurate estimates of water-budget components of a reservoir system are required to manage increased demands for available water supplies. Budget components such as withdrawals, diversions, return flows, change in storage contents, and tributary inflows usually can be quantified with direct measurements. Natural losses from the reservoir system, such as open-water evaporation, seepage, and evapotranspiration from riparian vegetation, are quantified using methods that are more indirect. These components typically are estimated with a variety of methods such as empirically derived relations developed with data collected at other locations, calculations using data and results from regional studies, statistically distributing water-budget residuals to selected components, or applying reasonable assumptions about the hydrodynamics of a reservoir system.

Open-water evaporation is a significant loss of water from Lake Mead. From 1953 to 1994, evaporation of water from Lake Mead was estimated to be $6.4 \mathrm{ft} / \mathrm{yr}$, or about 791,000 acre-ft/yr (based on an average surface area of 125,600 acres). From 1955 to August 1995, the U.S. Geological Survey (USGS) computed Lake Mead evaporation using a mass-transfer method. Data required for using this method are wind speed and water temperature, collected at a floating platform in Boulder Basin, and air temperature and vapor pressure, collected at an airport in Las Vegas, Nev., and reported by the National Weather Service (Harbeck, 1958a). In September 1995, the Bureau of Reclamation removed the floating platform from the lake and the wind-speed and watertemperature data required for the evaporation computation were no longer available. Alternative data sources (such as National Park Service data) were investigated, but due to the empirical nature of the method, were determined to be inadequate for estimating evaporation rates.

As a result, the Bureau of Reclamation proposed a cooperative study with the USGS to develop a method to estimate Lake Mead evaporation rates and to evaluate previously reported rates. The method developed by the USGS would be transferable to other large open-water areas managed by the Bureau of Reclamation or other agencies in the arid Southwest.

\section{Purpose and Scope}

This report presents the results of a study to refine estimates of evaporation from Lake Mead. Previously, estimated evaporation from Lake Mead (1955-95) may not be representative because of the methods used, and because some data used in the mass-transfer method were collected in the Las Vegas Valley rather than at the surface of the lake. In this report, previously used methods of computing evaporation are described, evaluated, and compared to those used in the current study for data collected for 1997-99, and to alternative methods of computing evaporation using modern (2005) equipment and techniques. Additionally, selected data collected during previous and current studies are summarized, including monthly and annual Lake Mead evaporation rates for 1952-95 and 1997-99.

To better refine estimates of evaporation from Lake Mead, atmospheric and water properties were collected from 1997 to 1999 at four floating platforms, which were installed in water of varying depth and fetch to sample differing environmental conditions at the lake. Near-continual data collected at Overton Arm, Boulder Basin, Virgin Basin, and near Callville Bay (fig. 1) were used with an energy-budget method to determine daily, monthly, and annual evaporation rates for 1997-99. 


\section{Estimating Evaporation from Lake Mead}

Lake Mead evaporation was computed using micrometeorological data collected at four floating instrumented platforms deployed in Water Barge Cove near Callville Bay, in Boulder Basin near Sentinel Island, in the Virgin Basin, and in the Overton Arm near Echo Bay (fig. 1). Platform station identifier, name, and date of installation are listed in table 2.
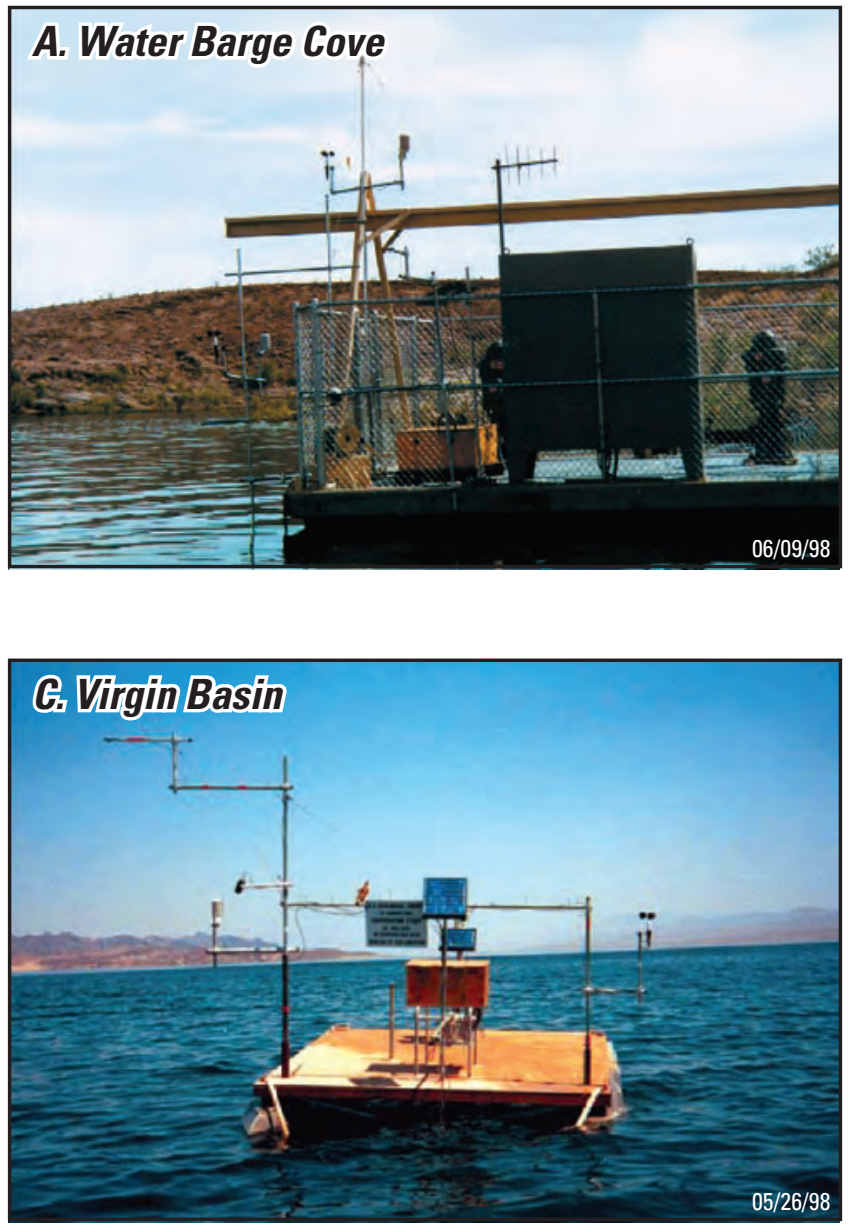

The platform in Water Barge Cove (site A) was in a relatively shallow cove protected from prevailing winds (figs. 1 and 2). The platforms in Boulder Basin near Sentinel Island (site B), Virgin Basin (site C), and Overton Arm (site D) were in different areas of the lake that are representative of open-water conditions in each basin. The depth of water at the four platforms fluctuated during the study due to water-level changes of Lake Mead. Lake elevation ranged from less than 1,196 ft in February 1997 to almost 1,216 ft in September 1998 (fig. 3).
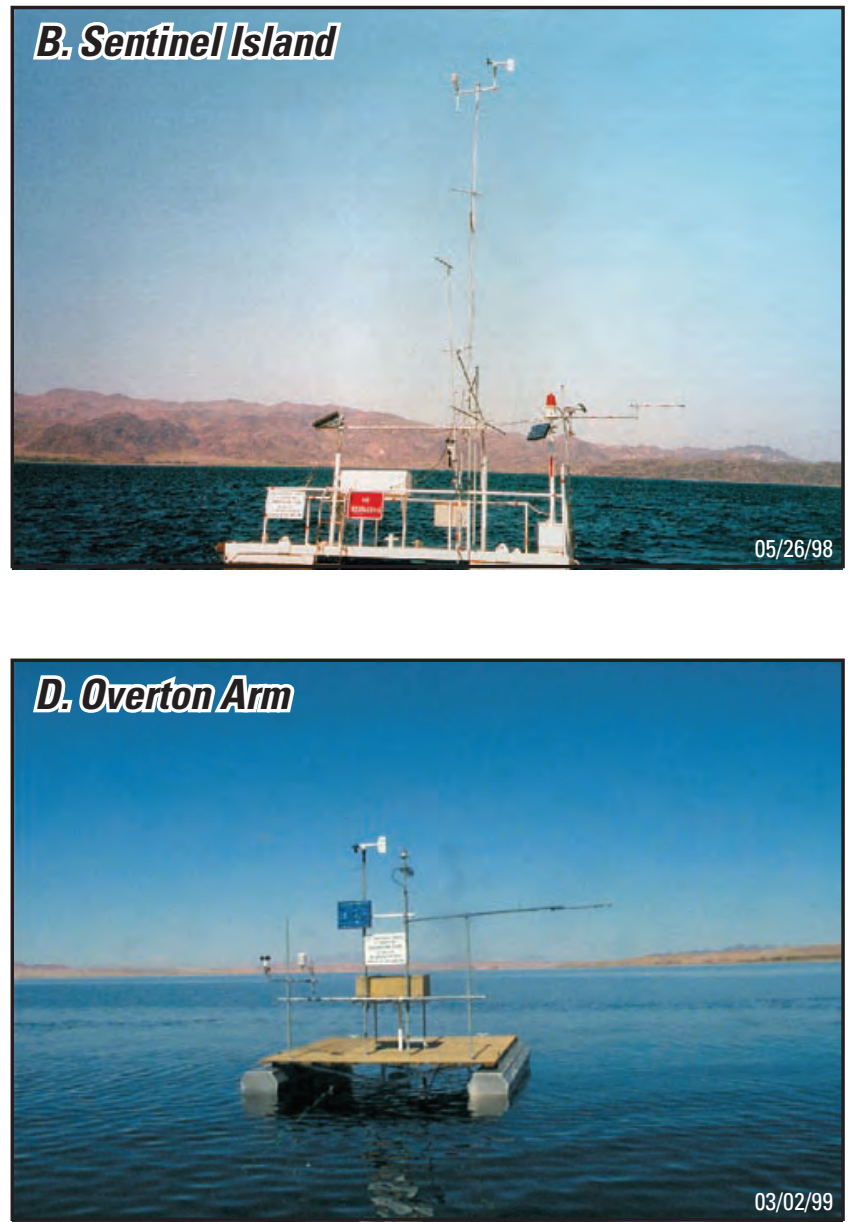

Figure 2. Four floating platforms on Lake Mead. Photographs taken by Craig L. Westenburg, U.S. Geological Survey. 
Table 2. Site information for four floating instrumented platforms used to collect data to compute evaporation from Lake Mead, Arizona and Nevada, 1997-99.

[Symbol: -, not applicable]

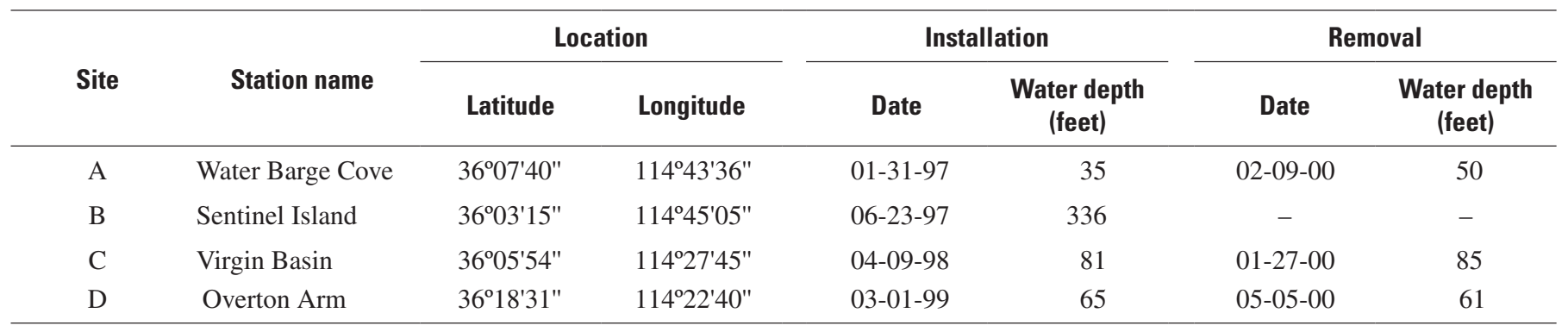

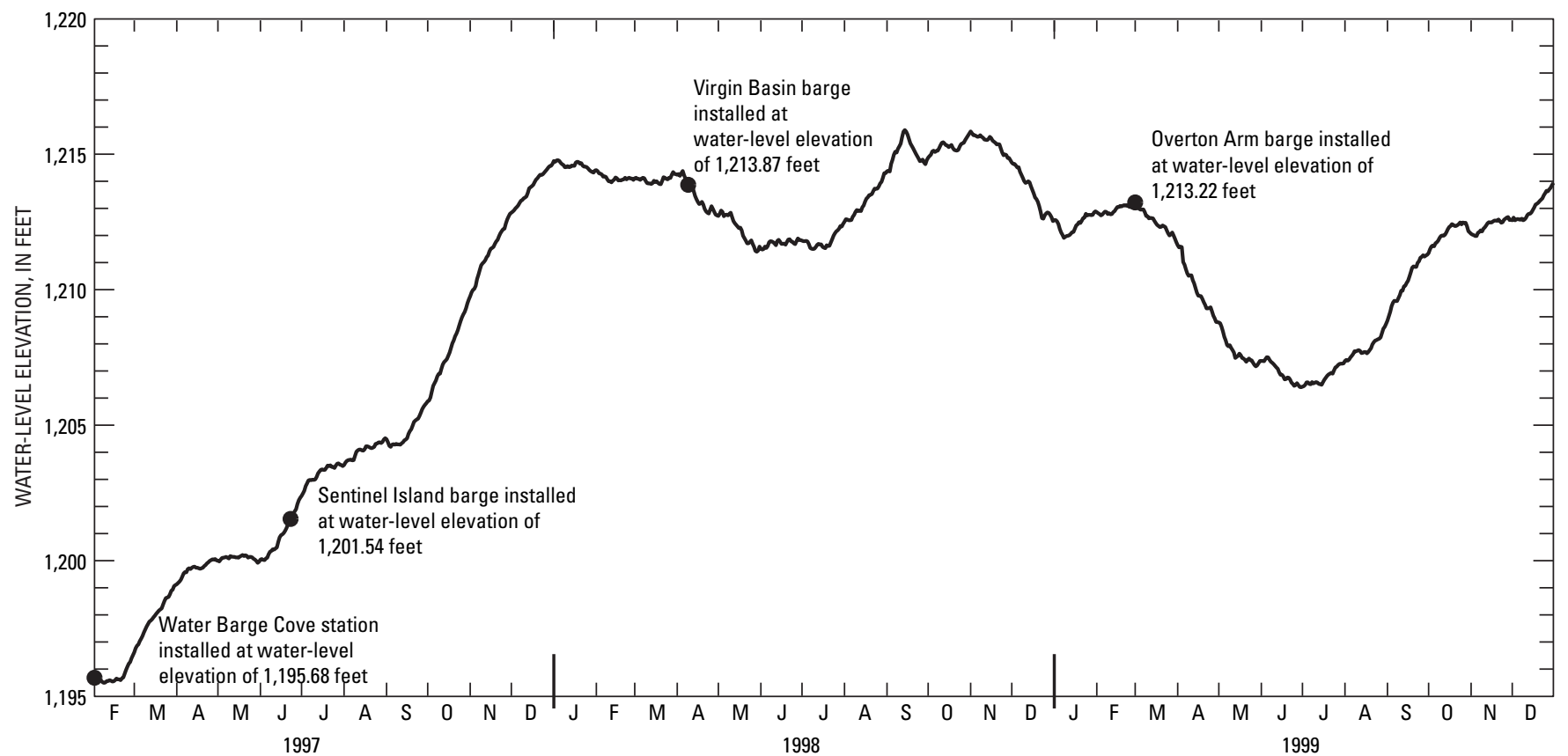

Figure 3. Lake Mead daily water-level elevation and date of station installation, February 1997-December 1999.

Each floating platform was equipped with instruments to measure and record meteorological data and water temperature. Air temperature and relative humidity were measured with a temperature-humidity probe (THP), wind speed and direction were measured with an anemometer and wind monitor, net radiation was measured with a net radiometer, and water temperature was measured at various depths with temperature probes (fig. 4 table 3 ). A two-point mooring system was used to secure each barge to prevent drifting and maintain the directional aspect of the wind monitor and net radiometer. The number of months with complete data, collected at four floating platforms for 1997-99, used to compute evaporation from Lake Mead is listed in table 4. 
Table 3. Description of data, collected at four floating instrumented platforms, used to compute evaporation from Lake Mead, Arizona and Nevada, 1997-99.

[Symbol: -, no remark]

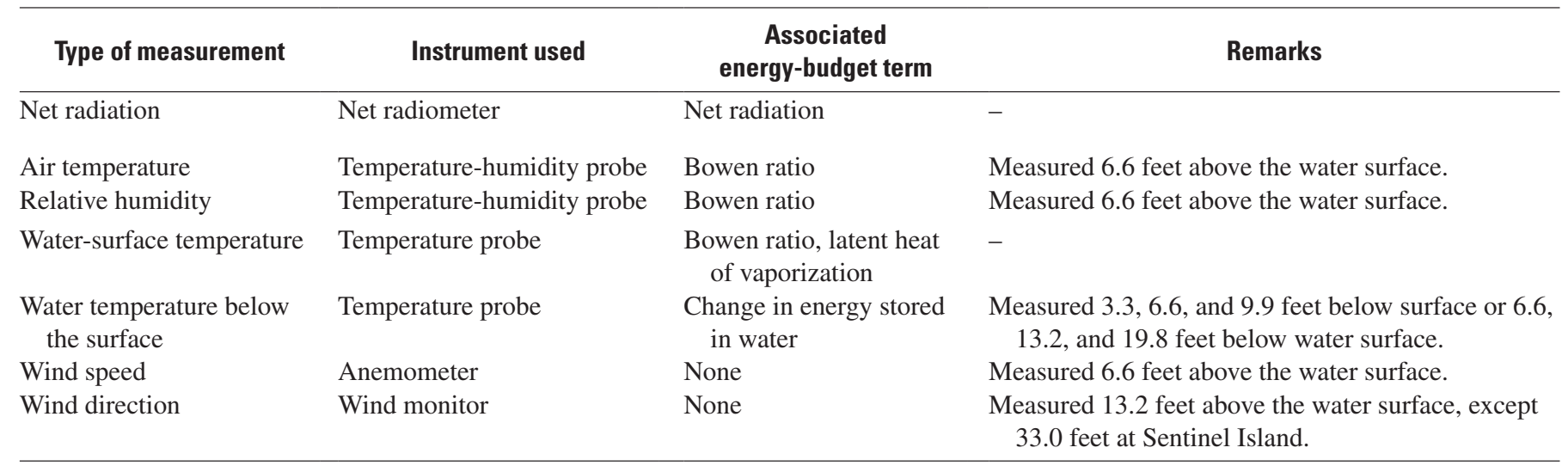

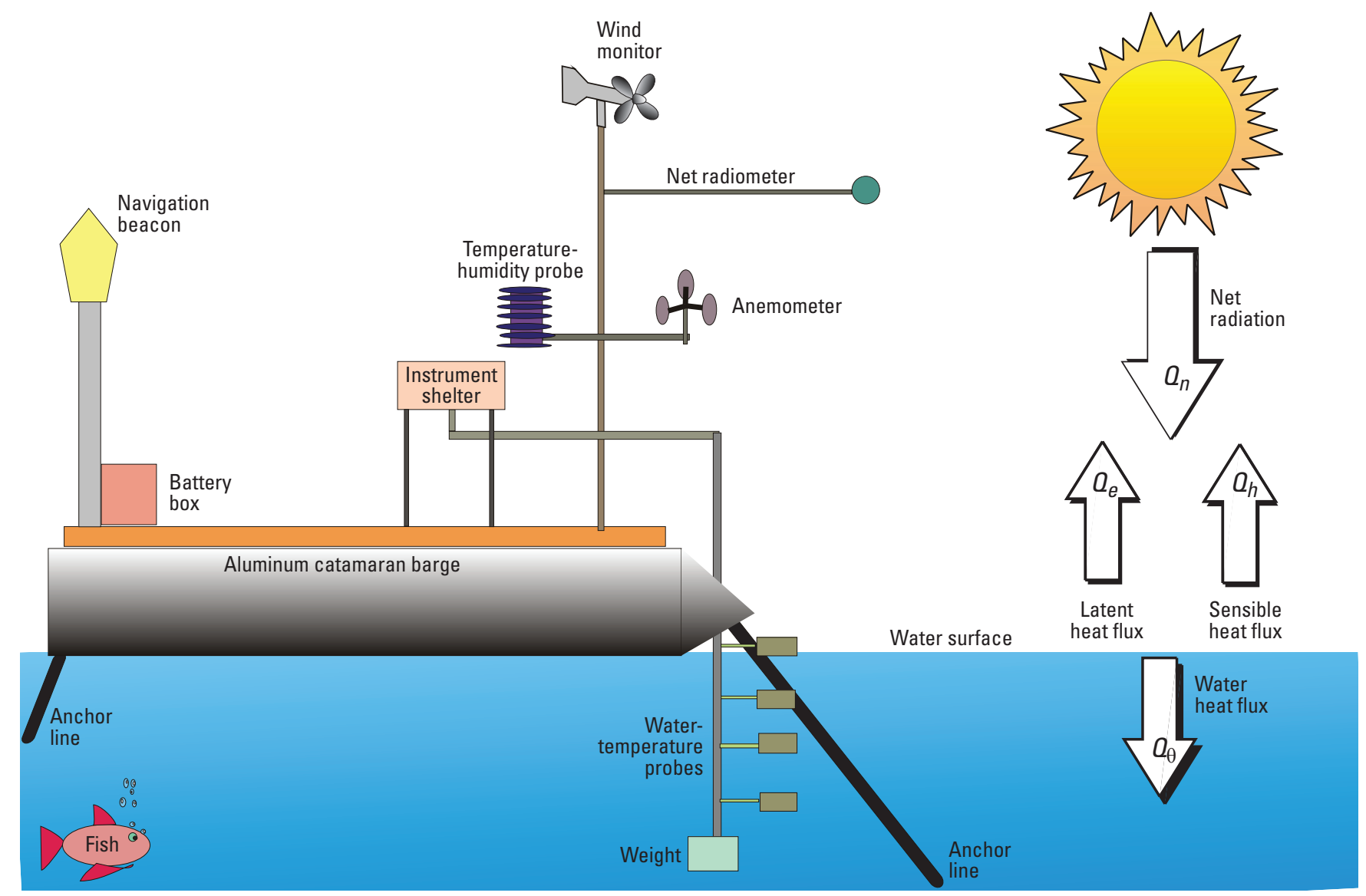

Figure 4. Instrument configuration on floating platforms on Lake Mead, Arizona and Nevada, and of energy fluxes at water surface. 
Table 4. Number of months with complete data, collected at four floating instrumented platforms, used to compute evaporation from Lake Mead, Arizona and Nevada, 1997-99.

[Distances are height above water surface, except water temperature, which is depth below water surface. Symbol: -, no data]

\begin{tabular}{|c|c|c|c|c|c|c|c|c|c|}
\hline Parameter & \multicolumn{3}{|c|}{ Water Barge Cove } & \multicolumn{3}{|c|}{ Sentinel Island } & \multicolumn{2}{|c|}{ Virgin Basin } & $\begin{array}{c}\text { Overton Arm } \\
1999\end{array}$ \\
\hline \multicolumn{10}{|l|}{ Air temperature } \\
\hline 6.6 feet & 9 & 12 & 12 & 6 & 12 & 10 & 8 & 12 & 10 \\
\hline 13.2 feet & 9 & 12 & - & - & - & - & - & - & - \\
\hline 33.0 feet & - & - & - & 6 & 12 & 10 & - & - & - \\
\hline 13.2 feet & 9 & 12 & - & - & - & - & - & - & - \\
\hline 33.0 feet & - & - & - & 6 & 12 & 10 & - & - & - \\
\hline \multicolumn{10}{|l|}{ Wind speed } \\
\hline 6.6 feet & 9 & 12 & 12 & 5 & 12 & 10 & 8 & 12 & 9 \\
\hline 13.2 feet & 9 & 12 & - & - & - & - & - & - & - \\
\hline Water temperature below surface & 9 & 12 & 12 & 6 & 12 & 10 & 8 & 12 & 10 \\
\hline 3.3 feet & 9 & 12 & - & - & - & - & - & - & - \\
\hline 6.6 feet & - & - & - & 6 & 12 & 10 & 8 & 12 & 10 \\
\hline 9.9 feet & 9 & 12 & - & - & - & - & - & - & - \\
\hline 13.2 feet & 9 & 12 & 12 & 6 & 12 & 10 & 8 & 12 & 10 \\
\hline 19.8 feet & - & - & - & 6 & 12 & 10 & 8 & 12 & 10 \\
\hline
\end{tabular}

\section{Energy-Budget Method}

The energy-budget method was used to measure evaporation from Lake Mead. This method also was used to quantify evaporation from western reservoirs in the 1950s (Anderson, 1954), and has been used by the USGS on a few long-term lake studies (Sturrock and Rosenberry, 1992; Rosenberry and others, 1993; Swancar and others, 2000). The energy-budget method is the most accurate method for measuring lake evaporation (Winter, 1981). Use of the energybudget method requires a large amount of data collection, but the effort is important because accurate measurements of lake evaporation are rare. An energy budget is similar to a water budget in that the change in stored energy is equal to the fluxes in and out of the system. Energy drives the process of evaporation because the water at the surface of the lake must absorb a certain amount of energy (latent heat of vaporization; approximately 580 calories per gram) before the water will evaporate. After some derivation, the following equation is used to calculate evaporation from the lake (Anderson, 1954):

$$
E=\left(Q_{s}-Q_{r}-Q_{b}+Q_{v}-Q_{\theta}\right) /[\rho L(R+1)]
$$

where

$E$ is evaporation rate,

$Q_{s}$ is the solar radiation incident to the water surface,
$Q_{r}$ is the reflected solar radiation,

$Q_{b}$ is the net energy lost by the body of water through the exchange of long-wave radiation between the atmosphere and the body of water,

$Q_{v}$ is the net energy advected into the body of water,

$Q_{\theta}$ is the change in energy stored in the body of water,

$\rho$ is the density of evaporated water,

$L$ is the latent heat of vaporization, and

$R$ is the Bowen ratio.

Bowen (1926) expressed the ratio as:

$$
\left.R=\gamma\left[T_{0}-T_{a}\right) /\left(e_{0}-e_{a}\right)\right] P,
$$

where

$\gamma$ is an empirical constant,

$T_{0}$ is the temperature of the water surface,

$T_{a}$ is the temperature of the air,

$e_{0}$ is the vapor pressure of saturated air at the temperature $\left(T_{0}\right)$,

$e_{a}$ is the vapor pressure of the air above the water surface, and

$P$ is atmospheric pressure. 
Net radiation $\left(Q_{n}\right)$ was measured at Lake Mead evaporation platforms and replaces three energy terms $\left(Q_{s}, Q_{r}\right.$, and $\left.Q_{b}\right)$ in equation 1 . Net advected energy $\left(Q_{v}\right)$ is disregarded based on the assumption that advected energy is negligible during a 20 -minute evaporation period.

Thus, after modifying equation 1 by substituting for net radiation, removing the net advected energy term, and replacing $R$ with equation 2, evaporation can be estimated from measured meteorological and hydrological parameters:

$$
E=\left(Q_{n}-Q_{\theta}\right) /\left[\rho L \gamma_{c}\left[\left(T_{0}-T_{a}\right) /\left(e_{0}-e_{a}\right)\right]+1\right],
$$

where $\gamma_{c}$ is a psychrometric constant, a product of $\gamma$ and $P$ (Laczniak and others, 1999, p. 20-21).

\section{Meteorological Data}

Meteorological and water temperature data were used to compute evaporation rates for Lake Mead. Measurements were made every 10 or 30 seconds and were averaged for 20-minute periods. Some of the missing or incorrect 20-minute data were estimated or computed to maximize the amount of data available for the evaporation computation. Where data were missing for short periods, they were estimated from trends of the data before and after the periods of missing or incorrect data. Where data were missing or incorrect for longer periods, they were computed from other available data at that station, data from another station, or data for another year. Typically, a regression was developed with two sets of measurements for a different period, but for similar environmental conditions, using a complete set of data. The regression was then used to estimate the missing or incorrect data from a complete set of data.
Monthly values of meteorological data and water temperatures were computed from 20-minute averaged data collected at each station for 1997, 1998, and 1999 (table 5). Average daily air temperature was about the same at all four platforms (fig. 5), whereas relative humidity and water temperature were similar at the open-water platforms. Generally, water temperature was higher and relative humidity was lower at the sheltered cove platform (Water Barge Cove) than at the open-water platforms.

Daily air temperature, water temperature, and relative humidity at the Sentinel Island station were compared for 1997, 1998, and 1999 (fig. 6). Air temperature varies from year to year, but the seasonal pattern is consistent. The maximum daily air temperature occurs about mid-July, with some daily average air temperatures exceeding $95^{\circ} \mathrm{F}$, and the minimum daily air temperature occurs from late December through February. Water temperature did not vary much from year to year. Maximum daily water temperature occurs in late July to early August and the minimum daily water temperature occurs in late February. Relative humidity fluctuated from day to day and differed greatly from year to year (fig. 6). However, there is a seasonal pattern of high relative humidity in January that gradually decreases to a low at the end of June, followed by a gradual increase to higher relative humidity in December.

Daily average wind-speed and direction data for 1999 are plotted in figure 7. Points are plotted a distance from the origin relative to the wind speed and in the direction from the origin that represents wind direction (measured with zero degrees $\left(0^{\circ}\right)$ corresponding to a north wind). Thus, a daily average wind speed of $5 \mathrm{mi} / \mathrm{hr}$ with a direction of $120^{\circ}$ would be plotted on the circle representing $5 \mathrm{mi} / \mathrm{hr}$ and in the lower right quadrant. Daily average wind speeds of less than $1 \mathrm{mi} / \mathrm{hr}$ were not plotted to avoid a dense cluster of points at the origin. Wind direction was predominately from the southeast to the southwest, occasionally from the northwest, and rarely from the northeast. Most daily wind speeds were less than $10 \mathrm{mi} / \mathrm{hr}$. The Virgin Basin location experienced more daily wind greater than $10 \mathrm{mi} / \mathrm{hr}$ than other locations. 
Table 5. Monthly mean meteorological and water-temperature data measured at four floating instrumented platforms on Lake Mead, Arizona and Nevada, 1997-99.

[Symbol: -, no data]

\begin{tabular}{|c|c|c|c|c|c|c|c|c|c|c|c|c|}
\hline Site & Jan. & Feb. & Mar. & Apr. & May & June & July & Aug. & Sept. & Oct. & Nov. & Dec. \\
\hline \multicolumn{13}{|c|}{ Air temperature, in degrees Fahrenheit } \\
\hline Water Barge Cove & - & 54.3 & 62.6 & 66.2 & 90.32 & 83.12 & 86.9 & 88.9 & 81.3 & 68.4 & 58.5 & 48.6 \\
\hline Sentinel Island & - & - & - & - & - & - & 90.1 & 90.7 & 81.9 & 76.8 & 59.7 & 50.4 \\
\hline Virgin Basin & - & - & - & - & - & - & - & - & - & - & - & - \\
\hline Overton Arm & - & - & - & - & - & - & - & - & - & - & - & - \\
\hline Water Barge Cove & - & 55.9 & 59.5 & 62.1 & 68.5 & 78.1 & 81.9 & 84.4 & 82.6 & 74.1 & 66.2 & 59.9 \\
\hline Sentinel Island & - & - & - & - & - & - & 79.7 & 82.6 & 81.1 & 79.9 & 65.8 & 57.2 \\
\hline Virgin Basin & - & - & - & - & - & - & - & - & - & - & - & - \\
\hline Overton Arm & - & - & - & - & - & - & - & - & - & - & - & - \\
\hline \multicolumn{13}{|c|}{ Water temperature, in degrees Fahrenheit, measured at 6.6 feet below the water surface } \\
\hline Water Barge Cove & - & 55.9 & 58.6 & 61.3 & 75.0 & 77.0 & 80.6 & 83.1 & 81.5 & 73.4 & 65.8 & 59.7 \\
\hline \multicolumn{13}{|c|}{ Relative humidity, in percent } \\
\hline Water Barge Cove & - & 40 & 34.9 & 33.6 & 25.0 & 29.6 & 31.5 & 37.9 & 47.9 & 37.5 & 47.9 & 43.0 \\
\hline Sentinel Island & - & - & - & - & - & - & 33.8 & 38.5 & 50.1 & 44.0 & 50.1 & 45.7 \\
\hline Virgin Basin & - & - & - & - & - & - & - & - & - & - & - & - \\
\hline Overton Arm & - & - & - & - & - & - & - & - & - & - & - & - \\
\hline \multicolumn{13}{|c|}{ Wind speed, in miles per hour, measured at 6.6 feet above the water surface } \\
\hline Water Barge Cove & - & 6.02 & 5.12 & 6.91 & 6.35 & 7.52 & 5.48 & 6.38 & 4.54 & 5.37 & 3.53 & 4.41 \\
\hline Sentinel Island & - & - & - & - & - & - & 5.75 & - & 7.16 & 7.63 & 6.69 & 7.83 \\
\hline Virgin Basin & - & - & - & - & - & - & - & - & - & - & - & - \\
\hline Overton Arm & - & - & - & - & - & - & - & - & - & - & - & - \\
\hline \multicolumn{13}{|c|}{1998} \\
\hline Sentinel Island & 55.8 & 54.7 & 56.3 & 59.4 & 65.1 & 72.5 & 81.0 & 83.3 & 81.0 & 71.6 & 65.0 & 59.4 \\
\hline Virgin Basin & - & - & - & 59.0 & 63.3 & 70.5 & 80.6 & 82.9 & 79.9 & 70.2 & 63.9 & 57.9 \\
\hline Overton Arm & - & - & - & - & - & - & - & - & - & - & - & - \\
\hline \multicolumn{13}{|c|}{ Water temperature, in degrees Fahrenheit, measured at 6.6 feet below the water surface } \\
\hline Water Barge Cove & 56.7 & 56.1 & 58.3 & 61.2 & 68.3 & 74.7 & 83.3 & 84.7 & 81.7 & 72.3 & 65.3 & 59.7 \\
\hline Sentinel Island & 56.1 & 55.0 & 56.3 & 59.4 & 64.8 & 72.0 & 81.1 & 83.5 & 81.0 & 71.6 & 65.0 & 59.4 \\
\hline Virgin Basin & - & - & - & 59.4 & 64.0 & 71.2 & 81.3 & 83.5 & 80.6 & 70.9 & 64.4 & 58.6 \\
\hline Overton Arm & - & - & - & - & - & - & - & - & - & - & - & - \\
\hline \multicolumn{13}{|c|}{ Relative humidity, in percent } \\
\hline Water Barge Cove & 55.3 & 58.0 & 50.3 & 43.3 & 36.2 & 33.1 & 37.7 & 36.4 & 41.9 & 38.5 & 47.4 & 41.8 \\
\hline Sentinel Island & 57.0 & 58.6 & 50.3 & 43.3 & 37.0 & 34.3 & 39.2 & 38.3 & 44.0 & 41.7 & 47.6 & 45.6 \\
\hline Virgin Basin & - & - & - & 44.2 & 39.5 & 36.6 & 43.6 & 43.2 & 48.8 & 46.3 & 52.8 & 51.3 \\
\hline Overton Arm & - & - & - & - & - & - & - & - & - & - & - & - \\
\hline \multicolumn{13}{|c|}{ Wind speed, in miles per hour, measured at 6.6 feet above the water surface } \\
\hline Water Barge Cove & 4.38 & 7.65 & 5.91 & 6.85 & 7.14 & 6.00 & 6.17 & 6.40 & 6.13 & 5.10 & 4.88 & 6.60 \\
\hline Sentinel Island & 6.58 & 9.57 & 8.37 & 8.26 & 9.17 & 7.87 & 7.67 & 7.36 & 6.89 & 7.94 & 7.47 & 9.44 \\
\hline Virgin Basin & - & - & - & 8.19 & 9.87 & 9.15 & 8.03 & 8.05 & 8.43 & 7.87 & 7.70 & 9.04 \\
\hline Overton Arm & - & - & - & - & - & - & - & - & - & - & - & - \\
\hline
\end{tabular}


Table 5. Monthly mean meteorological and water-temperature data measured at four floating platforms on Lake Mead, Arizona and Nevada, 1997-99.-Continued

[Symbol: -, no data]

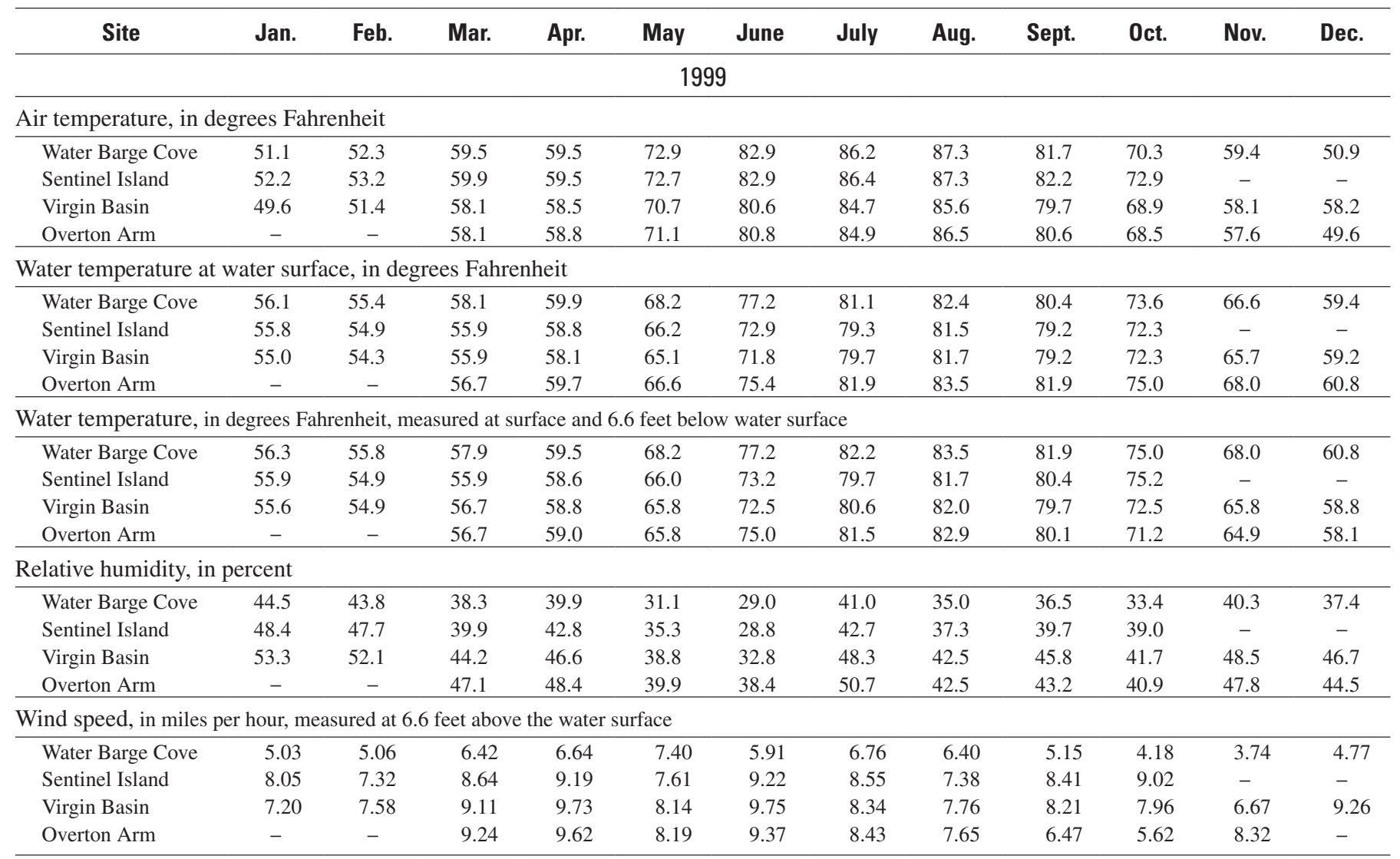



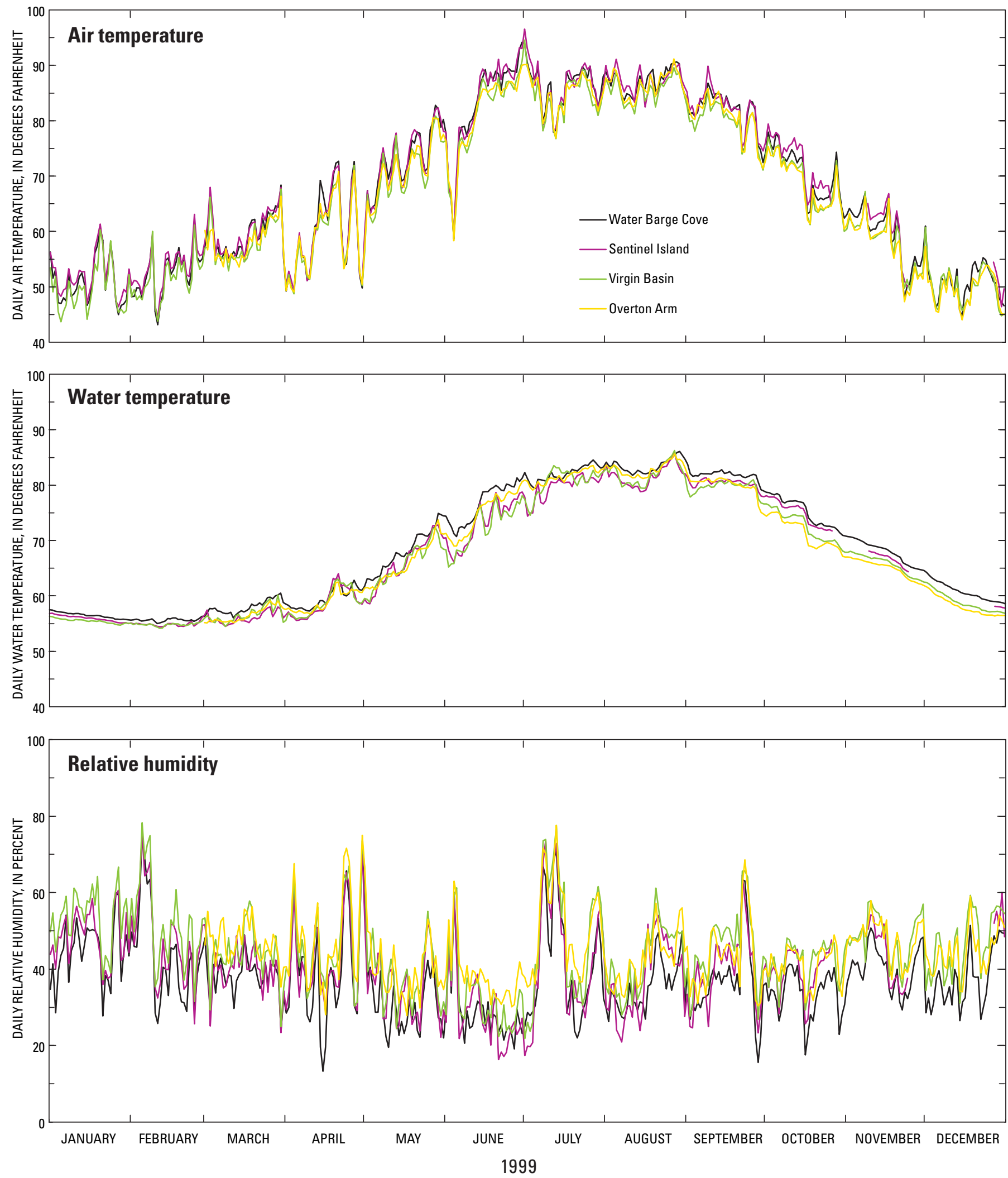

Figure 5. Air temperature, water temperature, and relative humidity collected at four floating instrumented platforms on Lake Mead, Arizona and Nevada, 1999. See figure 1 and table 2 for platform locations and site information. 

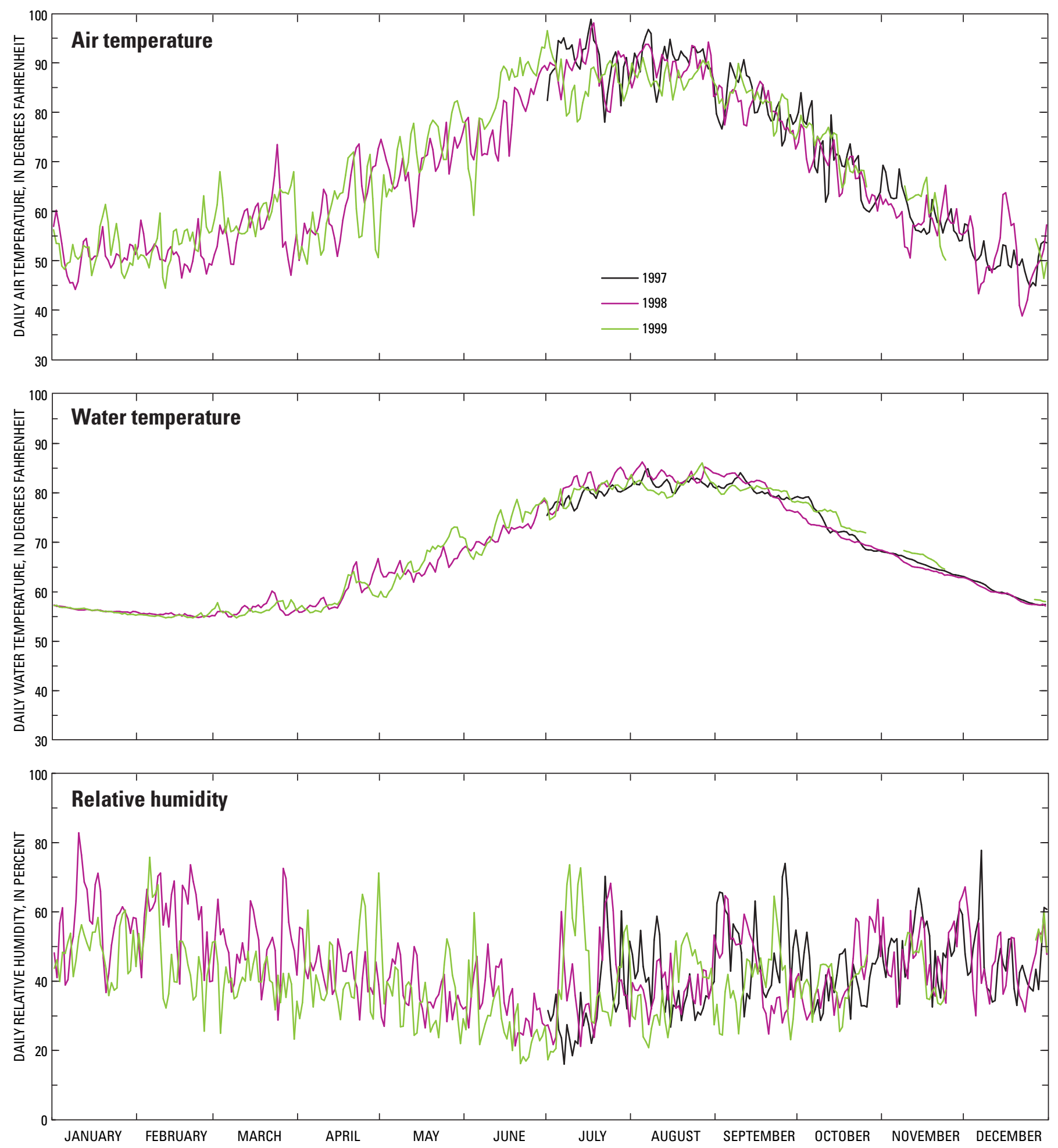

Figure 6. Air temperature, water temperature, and relative humidity collected at the Sentinel Island evaporation station, Nevada, 1997-99. 


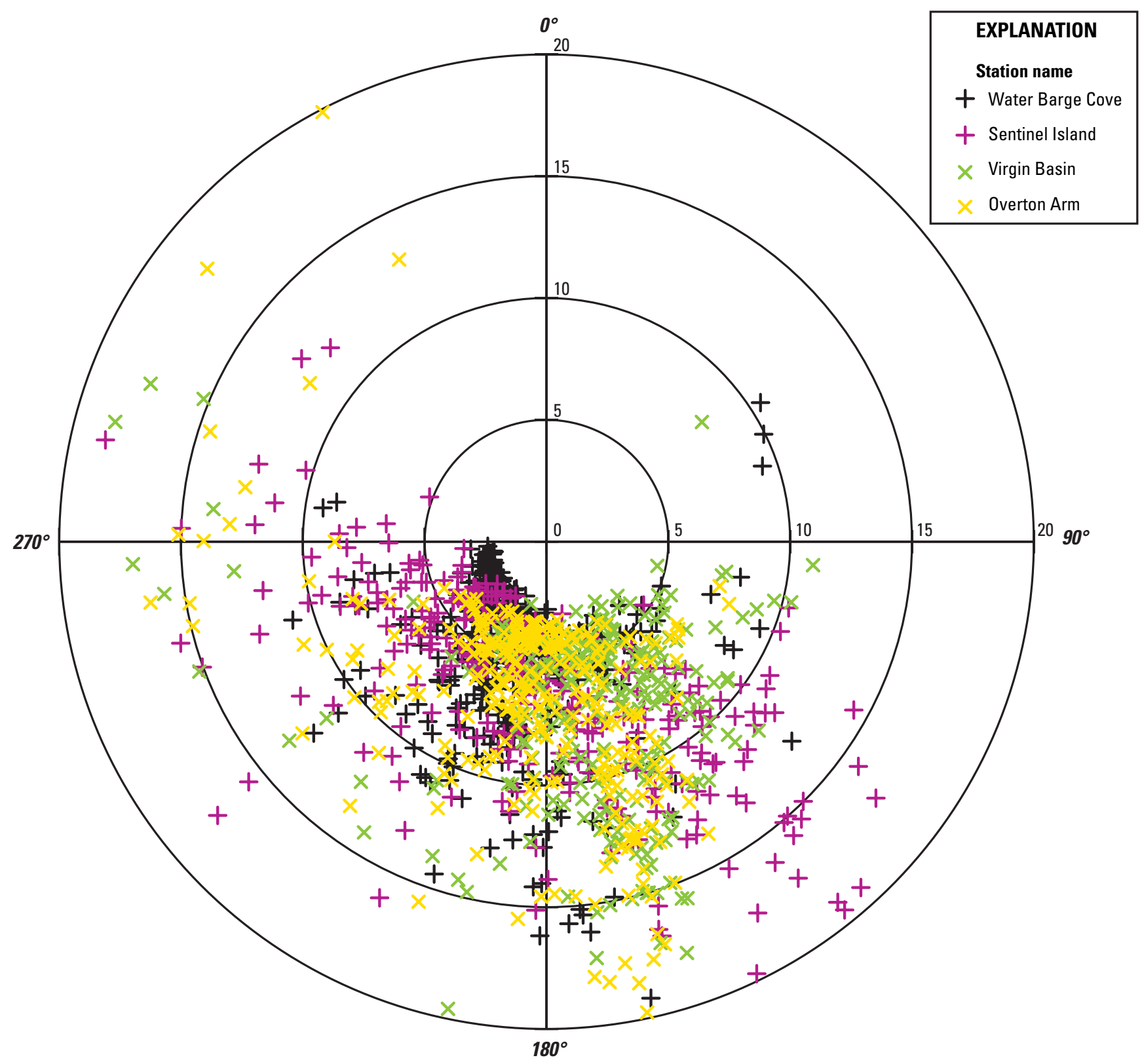

Figure 7. Wind speed and direction at four floating instrumented platforms on Lake Mead, Arizona and Nevada, 1999.

\section{Evaporation Rates}

Evaporation rates were computed at 20-minute intervals to evaluate diurnal fluctuations of lake evaporation. The 20minute period evaporation rates also were used to identify periods of poor or missing energy-budget data. Daily evaporation rates are the sum of 20-minute periods, monthly rates are the sum of daily evaporation and annual rates are the sum of monthly evaporation.

\section{Daily Rates}

Daily evaporation rates at the four evaporation stations were compared for calendar year 1999 (fig. 8) and showed similar daily fluctuations. However, the magnitude of fluctuations in daily evaporation was greater at Virgin Basin and Sentinel Island than at Overton Arm or Water Barge Cove. Daily evaporation was greatest from late June through early July and was least from mid-December through late January. 

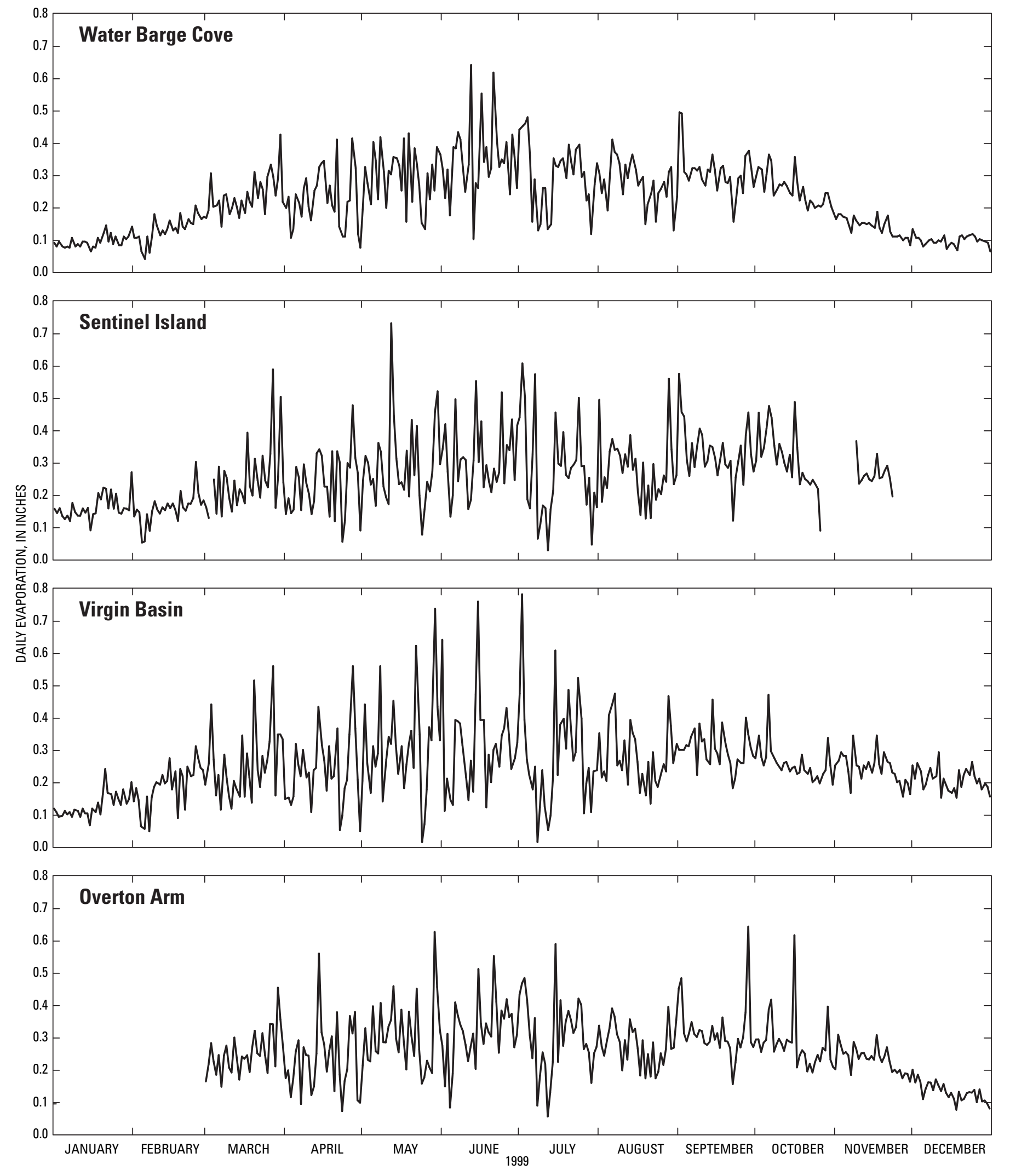

Figure 8. Daily evaporation rates at four floating instrumented platforms at Lake Mead, Arizona and Nevada, 1999. 


\section{Monthly Rates}

To evaluate the temporal variation in monthly evaporation at each station, monthly evaporation rates for each station were averaged and compared to the total evaporation rate for each month of data collection. Temporal data were available for Water Barge Cove, Sentinel Island, and Virgin Basin stations (table 6); however, monthly data were insufficient for the Overton Arm station to compute average monthly evaporation. Total monthly evaporation rates at three stations, with some exceptions, generally were within 10 percent of average monthly rates; consequently, annual variation in monthly evaporation typically was minimal between 1997 and 1999. Some months, however, exhibited significant differences between average and total evaporation. These differences were as great as 31 percent at Water Barge Cove (February 1997; fig. 9A), 14 percent at Sentinel Island (January 1998 and 1999; fig. 9B), and 22 percent at Virgin Basin (December 1998 and 1999; fig. 9C). Some of the difference in monthly evaporation rates from year to year may be due to errors in meteorological and water-temperature data collected at each station, but yearto-year differences for most months likely are due to actual differences in evaporation.
To evaluate the spatial variation in evaporation, total monthly evaporation rates at all four stations were averaged for every month of data collection and the average was compared to the total monthly evaporation rate at each station (fig. 10A). For each station, total monthly evaporation rates compared well to average monthly rates with correlation coefficients of 0.96 or higher. However, total monthly evaporation at Water Barge Cove generally was less than total evaporation rates at the open-water stations when rates were less than $6.5 \mathrm{in}$. Total monthly evaporation rates for all three open-water stations were nearly equal and compared well to average evaporation rates (fig. 10B); correlation coefficients for Sentinel Island and Overton Arm were 0.98, and for Virgin Basin was 0.96. This evaluation suggests that the spatial variation in evaporation is minimal for open-water areas of Lake Mead.

The monthly volume of evaporated water was computed using the average monthly open-water evaporation rate, in feet, and the average monthly surface area of Lake Mead for July 1997 through December 1999, in acres, (calculated from water elevation data at URL: <http://www.usbr.gov/lc/riverops. $\underline{\mathrm{html}}>$ and the Reclamation area capacity tables, Bureau of Reclamation, 1967). The volume of water evaporated in 1 month ranged from 46,000 acre-ft in February 1998 to 126,000 acre-ft in July 1998.

Table 6. Total and average monthly evaporation from Lake Mead at four floating instrumented platforms, Arizona and Nevada, 1997-99.

[Evaporation data, in inches. Symbol: -, data not measured or computed]

\begin{tabular}{|c|c|c|c|c|c|c|c|c|c|c|c|c|}
\hline Site & Jan. & Feb. & Mar. & Apr. & May & June & July & Aug. & Sept. & Oct. & Nov. & Dec. \\
\hline Water Barge Cove & - & 5.4 & 9.1 & 7.9 & - & 10.8 & 10.8 & 9.2 & 8.3 & 7.6 & 4.1 & 2.6 \\
\hline Virgin Basin & - & - & - & - & - & - & - & - & - & - & - & - \\
\hline Overton Arm & - & - & - & - & - & - & - & - & - & - & - & - \\
\hline \multicolumn{13}{|c|}{ Total monthly evaporation, 1998} \\
\hline Sentinel Island & 3.7 & 3.6 & 7.1 & 7.4 & 9.9 & 9.4 & 10.0 & 8.9 & 8.9 & 8.5 & 7.3 & 6.0 \\
\hline Virgin Basin & - & - & - & 8.6 & 9.7 & 9.1 & 9.9 & 8.7 & 9.7 & 7.1 & 5.9 & 4.1 \\
\hline Overton Arm & - & - & - & - & - & - & - & - & - & - & - & - \\
\hline \multicolumn{13}{|c|}{ Average evaporation, 1998} \\
\hline \multicolumn{13}{|c|}{ Total monthly evaporation, 1999} \\
\hline Water Barge Cove & 3.0 & 3.8 & 7.4 & 6.8 & 9.2 & 10.5 & 9.4 & 8.7 & 9.4 & 8.0 & 4.3 & 3.1 \\
\hline Sentinel Island & 5.0 & 4.4 & 8.1 & 6.9 & 9.0 & 9.2 & 8.4 & 8.6 & 9.9 & 8.8 & 6.7 & - \\
\hline Virgin Basin & 4.0 & 5.3 & 7.9 & 7.1 & 9.6 & 9.3 & 8.8 & 8.7 & 9.1 & 8.0 & 7.3 & 6.5 \\
\hline Overton Arm & - & - & 7.8 & 6.9 & 9.5 & 9.5 & 9.4 & 8.6 & 9.5 & 8.7 & 7.0 & 4.1 \\
\hline \multicolumn{13}{|c|}{ Average evaporation, 1999} \\
\hline All available sites & 4.0 & 4.5 & 7.8 & 6.9 & 9.3 & 9.6 & 9.0 & 8.6 & 9.5 & 8.4 & 6.3 & 4.5 \\
\hline Open-water sites & 4.5 & 4.8 & 8.0 & 7.0 & 9.4 & 9.4 & 8.9 & 8.6 & 9.5 & 8.5 & 7.0 & 5.3 \\
\hline
\end{tabular}



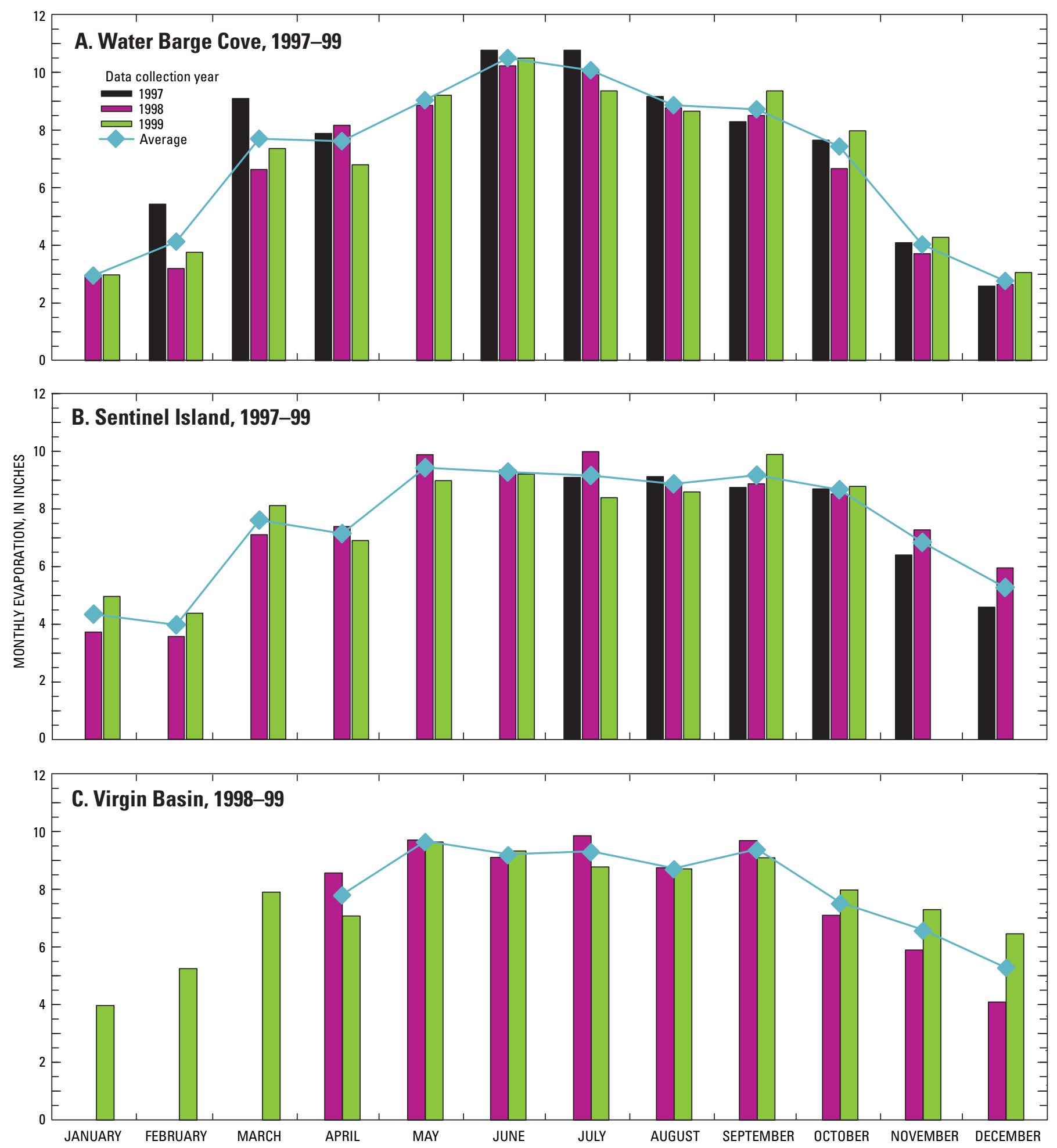

Figure 9. Total and average monthly evaporation at three floating instrumented platforms on Lake Mead, Arizona and Nevada, 1997-99. 


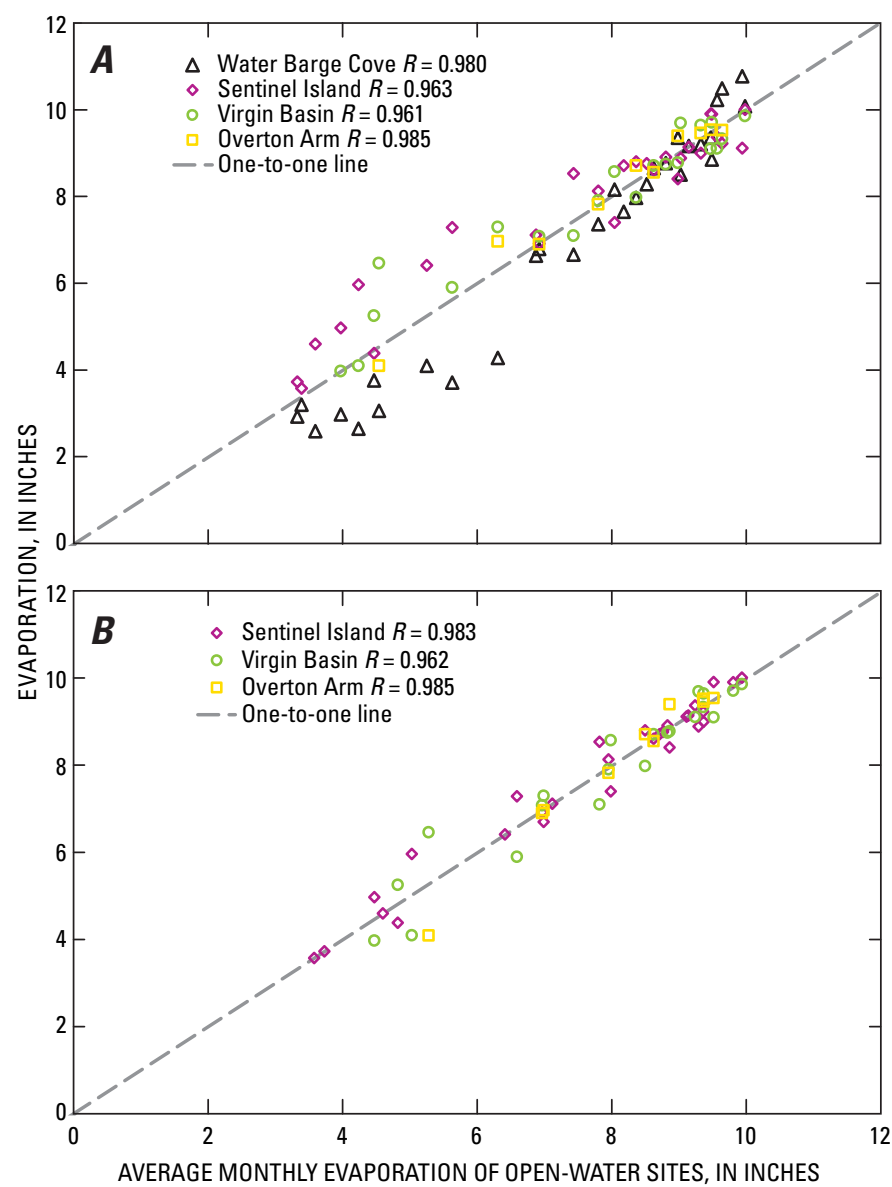

Figure 10. Comparison of total monthly evaporation at $(A)$ four evaporation stations with average monthly evaporation at all stations and $(B)$ three open-water evaporation stations with average monthly evaporation at open-water stations, April 1998-0ctober 1999. $R$ is correlation coefficient.

\section{Annual Rates}

The average monthly rates for the Lake Mead open-water evaporation stations were computed for 1998 and 1999. For open-water stations, the sum of the average monthly rates for 1998 was $88.9 \mathrm{in}$. (7.4 ft) and the sum for 1999 was 90.7 in. (7.6 ft; table 7). For these 2 years, the average annual Lake Mead evaporation rate was 89.8 in. (7.5 ft). Monthly evaporation rates were available for only the Sentinel Island station for January-March 1998, and those rates are used instead of an average rate.

Evaporation rates at the Sentinel Island station are generally representative of evaporation of the lake as a whole. For April 1998 through November 1999, the total evaporation at the Sentinel Island station was 161.3 in., whereas, the total of average monthly evaporation for the open-water stations was $159.9 \mathrm{in}$. The difference of 1.4 in. is less than 1 percent of the total average openwater evaporation.

The annual volume of water evaporated from Lake Mead exceeded 1.1 million acre-ft in 1998 and 1999 (table 7), which probably is higher than a long-term average annual evaporation due to higher-than-normal lake elevations and corresponding larger-than-normal surface area for the period. For example, the average surface area of Lake Mead was 125,000 acres from 1942 to 1995 and the computed average annual evaporation rate was $7.5 \mathrm{ft}$ from 1997 to 1998 , which would equal a long-term average annual volume of 937,500 acre-ft of evaporated water.

Table 7. Average monthly evaporation and computed monthly evaporative loss from Lake Mead, Arizona and Nevada, July 1997December 1999.

[Evaporation rate, in inches, are average rates for available open-water sites (table 6). Volume of water was computed by multiplying average open-water evaporation rates, converted to feet, by lake-surface area, in acres. Lake-surface area derived from area-capacity tables and mean daily elevation. For October 1997, monthly evaporation at Water Barge Cove was used. Symbol: -, data not computed]

\begin{tabular}{|c|c|c|c|c|c|c|c|c|c|c|c|c|c|}
\hline & Jan. & Feb. & Mar. & Apr. & May & June & July & Aug. & Sept. & Oct. & Nov. & Dec. & Annual \\
\hline 1997 & - & - & - & - & - & - & 9.1 & 9.1 & 8.8 & 8.7 & 6.4 & 4.6 & - \\
\hline 1999 & 4.5 & 4.8 & 8.0 & 7.0 & 9.4 & 9.4 & 8.9 & 8.6 & 9.5 & 8.5 & 7.0 & 5.3 & 90.7 \\
\hline Average & 4.1 & 4.2 & 7.5 & 7.6 & 9.6 & 9.3 & 9.3 & 8.8 & 9.2 & 8.3 & 6.7 & 5.0 & ${ }^{1} 89.8$ \\
\hline 1998 & 48,000 & 46,000 & 91,000 & 102,000 & 125,000 & 117,000 & 126,000 & 113,000 & 119,000 & 101,000 & 85,000 & 64,000 & $1,137,000$ \\
\hline 1999 & 57,000 & 61,000 & 101,000 & 88,000 & 117,000 & 116,000 & 110,000 & 108,000 & 120,000 & 108,000 & 89,000 & 67,000 & $1,142,000$ \\
\hline
\end{tabular}

${ }^{1}$ Average annual evaporation rate is only for 1998-99. 


\section{Previously Reported Evaporation Rates}

The reported average annual evaporation of $6.4 \mathrm{ft}$ from 1953 through 1994 (fig. 11, table 8) is 15 percent less than the estimated average annual evaporation of $7.5 \mathrm{ft}$ from 1997 to 1999. The USGS reported monthly evaporation rates for Lake Mead from October 1953-September 1995 (U.S. Geological Survey, 1961-64, 1965-75, 1976-82; Hendricks, 1964; Frisbie and others, 1983-85; Pupacko and others, 1988, 1989a, 1989b, 1990; Bostic and others, 1991; Garcia and others, 1992; Hess and others, 1993; Emett and others, 1994; Clary and others, 1995; Bauer and others, 1996). Harbeck (1958b, table 13, p. 37) reported monthly evaporation rates for March 1952 to September 1953. G.E. Koberg (U.S. Geological Survey, written commun., 1964) revised the reported monthly evaporation rates for October 1952 to September 1962; however, those revised rates were never published. Koberg did not revise the reported monthly rates for March 1952 to September 1952. Previously reported evaporation rates were not entered in a database or summarized in any single publication; these rates were available only from the various publications and written communications.
The average annual evaporation, average monthly evaporation, and standard deviation of monthly rates were compared for two periods of previously estimated Lake Mead evaporation, 1953-73 and 1974-94. Evaporation rates were available for 12 months of each year during those periods and each period consists of 21 years (table 8). The average annual evaporation for 1953-73 is $6.7 \mathrm{ft}$; whereas, the average annual evaporation for 1974-94 is $6.0 \mathrm{ft}$. Compared to 1974-94, the mean monthly evaporation during 1953-73 was greater for every month except November.

The standard deviation (variability) of monthly evaporation rates for 1953-73 was less than for 1974-94 for every month except May. Only the annual rates of $5.9 \mathrm{ft}$ in 1965 and $7.4 \mathrm{ft}$ in 1956 differed from the average annual rate of $6.7 \mathrm{ft}$ for 1953-73 by greater than 10 percent. In contrast, annual evaporation was more variable for 1974-94 with rates for 9 years that differed by more than 10 percent from the average annual rate of $6.0 \mathrm{ft}$. The greater variability probably was related to estimated monthly wind speed due to mechanical problems with the anemometer at Lake Mead.

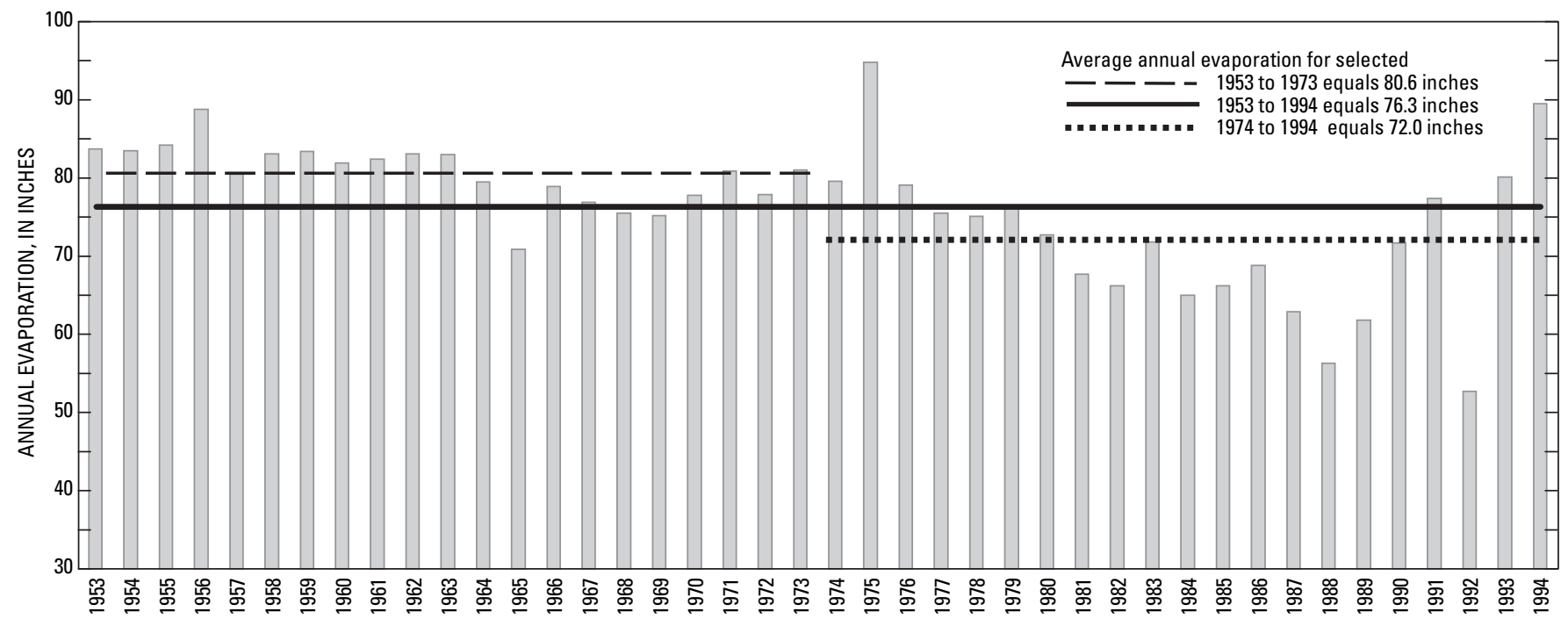

Figure 11. Annual Lake Mead evaporation, 1953-94. 
Table 8. Total monthly, total annual, and average monthly Lake Mead evaporation, 1953-95.

[Historical references for this table are U.S. Geological Survey, 1961-64, 1965-75, 1976-82; Hendricks, 1964; Frisbie and others, 1983-85; Pupacko and others, 1988, 1989a, 1989b, 1990; Bostic and others, 1991; Garcia and others, 1992; Hess and others, 1993; Emett and others, 1994; Clary and others, 1995; and Bauer and others, 1996. Symbol:-, no data available]

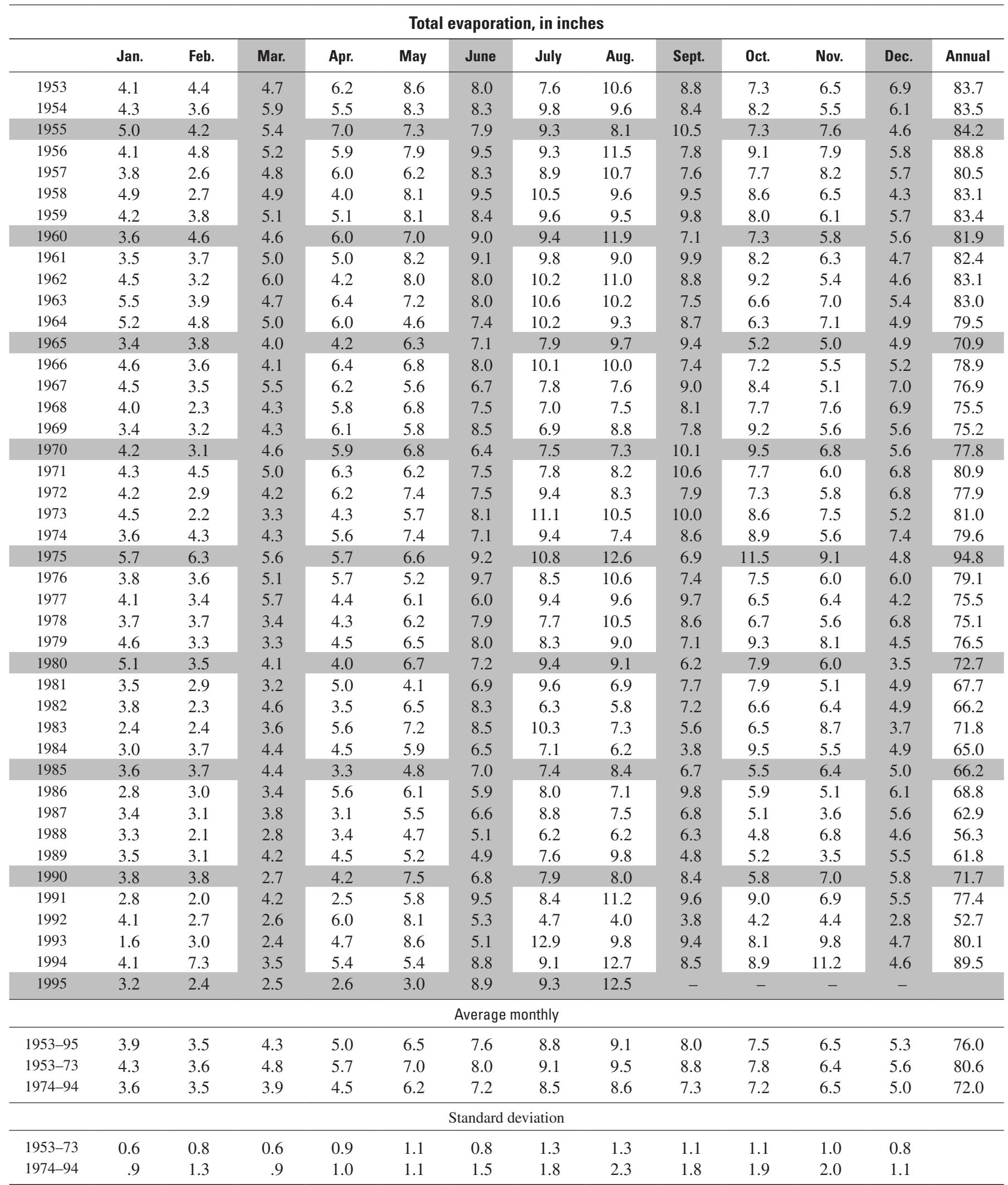




\section{Alternative Methods of Estimating Lake Mead Evaporation}

Two alternative methods were examined for estimating Lake Mead evaporation: (1) continuing operation of a complete open-water energy-budget station and (2) estimating evaporation with daily net radiation measured at a readily accessible location on Lake Mead.

Based on results of the current study, operation of one complete energy-budget station located in an open-water area

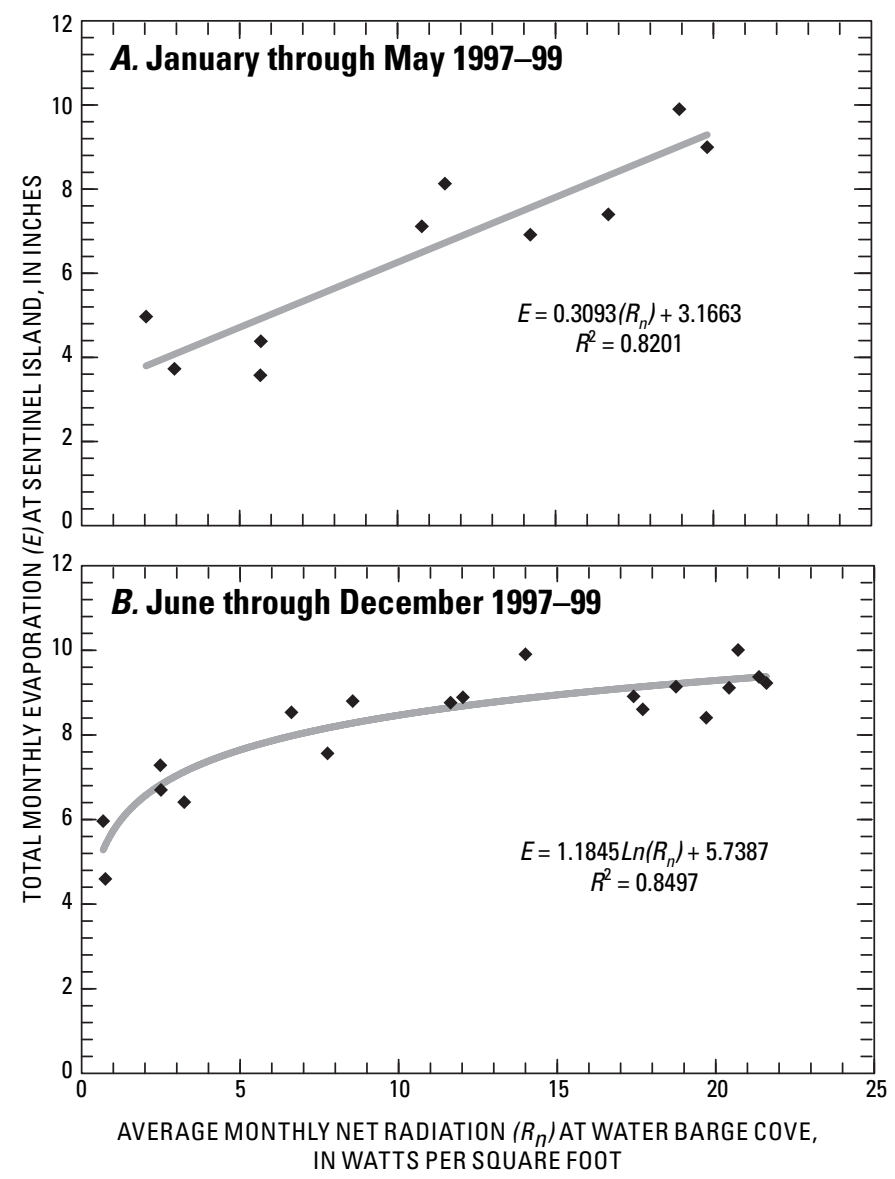

Figure 12. Regression of monthly average net radiation at the Water Barge Cove station and total monthly evaporation at Sentinel Island station for: $(A)$ January through May 199799 and $(B)$ June through December 1997-99. $R^{2}$ is coefficient of determination. of the lake would provide an accurate estimate of evaporation for all of Lake Mead. For example, monthly evaporation for the open-water station at Sentinel Island in Boulder Basin is within 5 percent of the estimated total monthly evaporation of all open-water areas of Lake Mead. This method requires standard measurements of water temperature at and below the water surface, air temperature, relative humidity, and net radiation. Also, because equipment on an open-water barge is exposed to extreme weather and water conditions, routine maintenance of station equipment is necessary.

A regression of average monthly evaporation at Sentinel Island (table 6) and net radiation at the Water Barge Cove station was developed for 29 months (1997-99) to determine the relation between net radiation at a station that is accessible (Water Barge Cove) and evaporation at an open-water station (Sentinel Island). The regression was developed for two periods of the year: January to May when heat storage in the lake is decreasing (fig. 12A), and (2) June to December when heat storage in the lake is increasing (fig. 12B). Data were plotted with net radiation at Water Barge Cove as the independent variable and Sentinel Island evaporation as the dependent variable. The coefficient was 0.820 for January to May and 0.850 for June to December, indicating that measurements of monthly average net radiation at Water Barge Cove, or a site with similar environmental conditions on the lake, may be used to approximate lake evaporation.

The accuracy of the net radiation alternative method was evaluated by applying empirical equations derived for each heat-storage period to determine total monthly evaporation and by comparing these estimates to the average monthly evaporation for open-water stations. Monthly average net radiation at Water Barge Cove was used to compute monthly evaporation from July 1997 through December 1999 (30 months) using empirical equations representing the best-fit lines (fig. 12):

$$
E=R_{n} * 0.3093+3.1663,
$$

(applied from January through May) and

$$
E=1.1845 * \operatorname{Ln}\left(R_{n}\right)+5.7387,
$$

(applied from January through May), where $R_{n}$ is monthly net radiation at Water Barge Cove, in Watts per square foot, and $E$ is monthly evaporation, in inches. 


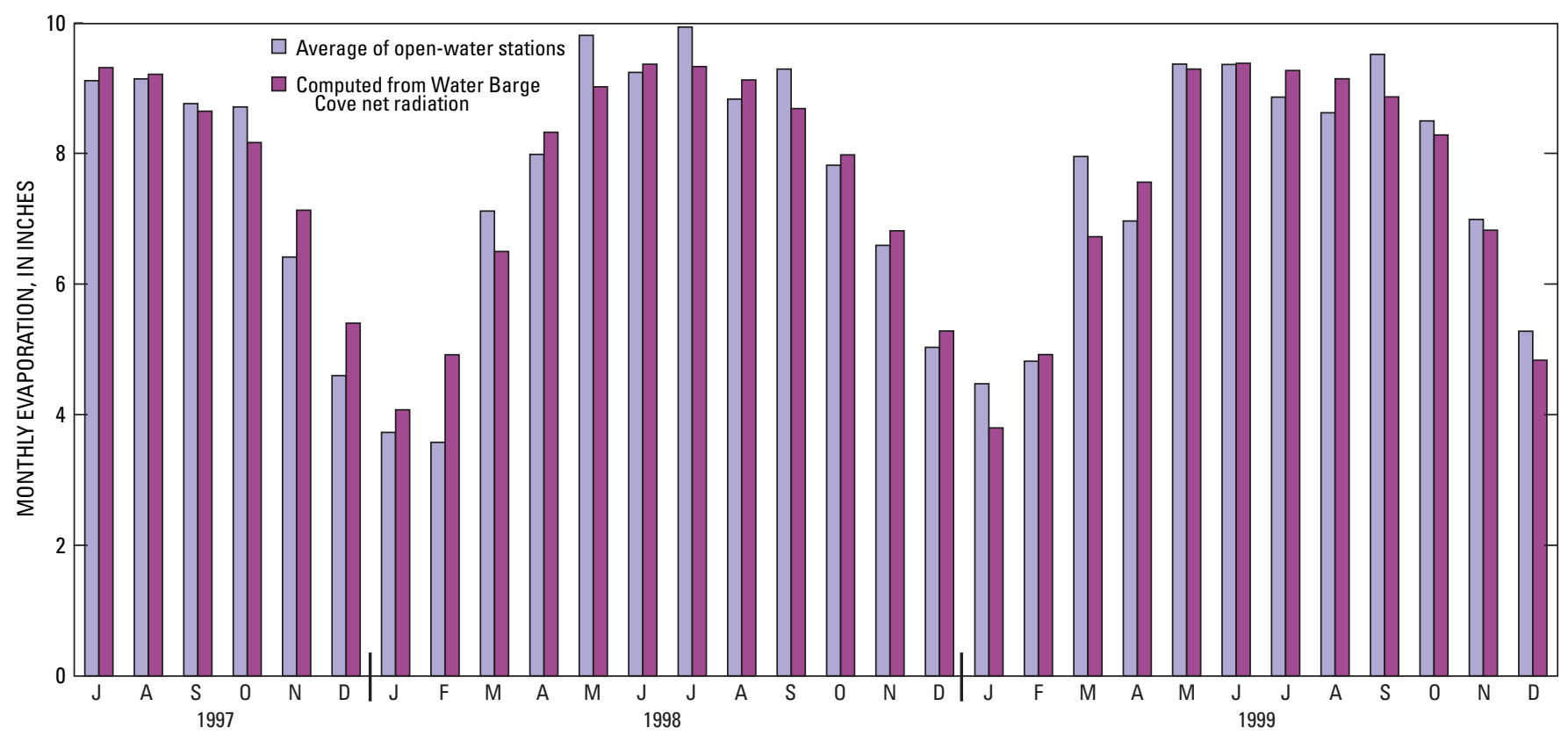

Figure 13. Total monthly evaporation (average of open-water stations) and total monthly evaporation computed from monthly average net radiation at the Water Barge Cove station.

Computed monthly evaporation rates were compared to average monthly evaporation at the open-water stations (fig. 13). The minimum and maximum monthly openwater evaporation rates were 3.6 in. (February 1998) and 9.9 in. (July 1998), respectively. Whereas, the minimum and maximum computed monthly evaporation rates from Water Barge Cove net radiation were 3.8 in. (January 1999) and 9.4 in. (June 1999), respectively. Of the 30 monthly evaporation rates compared, four monthly rates differed from open-water evaporation rates by more than 10 percent (fig. 14). The largest difference in evaporation rates was 37.5 percent for February 1998, and the average difference was 1 percent.

Monthly evaporation rates were summed to compare annual evaporation for open-water stations and computed evaporation using empirical equations. Total open-water evaporation was $7.4 \mathrm{ft}$ compared to a computed evaporation rate of $7.5 \mathrm{ft}$ for 1998 (a 1.4 percent difference). Additionally, open-water evaporation was $7.6 \mathrm{ft}$ compared to a computed rate of $7.4 \mathrm{ft}$ for 1999 (a 2.6 percent difference).

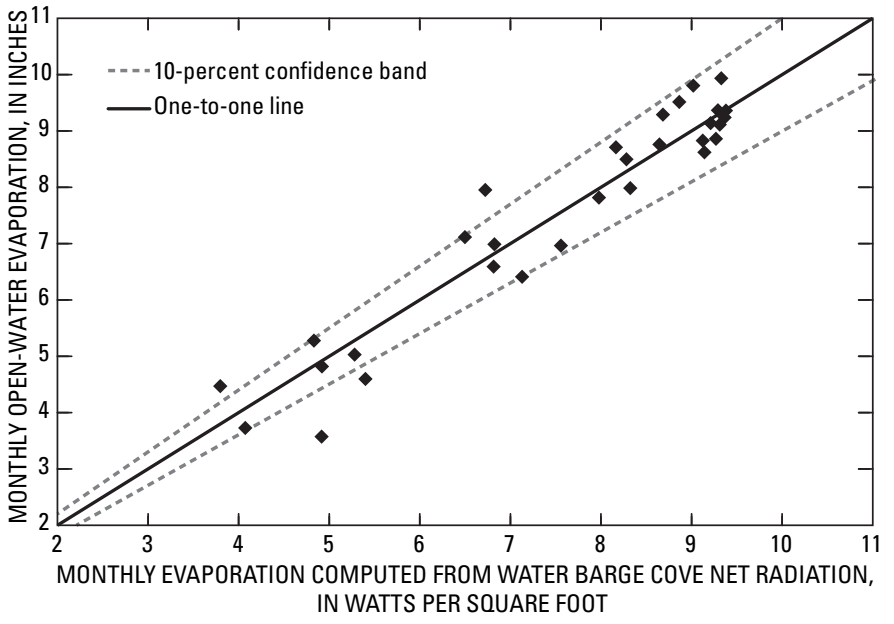

Figure 14. Comparison of total monthly evaporation (average of open-water stations) and monthly evaporation computed from monthly mean net radiation at the Water Barge Cove station. 


\section{Summary}

Air temperature, relative humidity, wind speed and direction, and water temperature were measured from 1997 to 1998 at four floating instrumented platforms on Lake Mead. One of four floating platforms was in a shallowwater sheltered area of Boulder Basin (Water Barge Cove); the remaining three platforms were in open-water areas of Boulder Basin, Virgin Basin, and Overton Arm. Data were averaged in 20-minute intervals and these averages were used with the energy-budget equation to compute estimates of lake evaporation.

Generally, micrometeorological and water-temperature data were similar at the open-water locations. Relative humidity and wind speed were lower, and water temperature was higher, at the sheltered cove platform (Water Barge Cove) than at the open-water platforms. Air temperature was about the same at all locations.

Monthly evaporation rates were evaluated for temporal variations at each station and spatial variations between stations. At each station, monthly evaporation rates did not significantly vary from year to year for the period of data collection. Moreover, spatial variation in monthly evaporation rates was minimal for the open-water stations. However, monthly evaporation at Water Barge Cove generally was less than monthly evaporation at other stations when the monthly evaporation rate was less than 6.5 in. Estimated monthly evaporation rates were summed for each year of data collection to determine annual evaporation rates. The average annual evaporation rate for Lake Mead from January 1998 to December 1999 was $7.5 \mathrm{ft}$.

The estimated annual evaporation of $7.5 \mathrm{ft}$ for the period 1997-99 is about 15 percent greater than previously reported annual rates of about $6.4 \mathrm{ft}$ for 1953-94, which was estimated using a mass-transfer equation that was derived initially during a 1952-53 Lake Mead water-loss study. Reported annual evaporation rates from 1953 to 1994 fluctuated from 6 to $7.5 \mathrm{ft} / \mathrm{yr}$ prior to 1975 ; after 1975, annual evaporation rates fluctuated from 4.4 to $7.9 \mathrm{ft} / \mathrm{yr}$.

During the 1997-99 study, monthly average netradiation data for a shallow-water site (Water Barge Cove) was regressed with monthly total evaporation data for an open-water site (Sentinel Island) to evaluate an alternative method of estimating lake evaporation. Empirical equations derived from this regression were used to compute monthly evaporation rates, and these rates were compared to average monthly evaporation rates at open-water stations. Only 4 of the 30 computed monthly evaporation rates differed from monthly open-water rates by more than 10 percent, indicating that monthly net radiation at Water Barge Cove, or a site with similar environmental conditions on the lake, may be used to approximate lake evaporation. Monthly evaporation rates were summed to compare annual evaporation for open-water sites and computed evaporation using empirical equations. Total open-water evaporation was $7.4 \mathrm{ft}$ compared to a computed evaporation rate of $7.5 \mathrm{ft}$ for 1998 (a 1.4 percent difference). Additionally, open-water evaporation was $7.6 \mathrm{ft}$ compared to a computed rate of $7.4 \mathrm{ft}$ for 1999 (a 2.6 percent difference).

\section{Acknowledgments}

Many agencies cooperated with the USGS during this evaporation study. The Bureau of Reclamation provided the USGS with a boat and a barge for meteorological equipment. The National Park Service provided temporary use permits, two barges, and space on a National Park Service pumping barge for meteorological equipment. They also provided historical Lake Mead weather data, manpower and equipment for anchoring barges, and security for the barges and equipment. The Las Vegas National Weather Service provided Las Vegas weather data.

\section{References Cited}

Anderson, E.R., 1954, Energy-budget studies, in Water-loss investigations, Lake Hefner studies, technical report: U.S. Geological Survey Professional Paper 269, p. 71-119.

Bauer, D.J., Foster, B.J., Joyner, J.D., and Swanson, R.A., 1996, Water resources data, Nevada, water year 1995: U.S. Geological Survey Water-Data Report NV-95-1, 734 p.

Bostic, R.E., Hitch, D.E., Van Gordon, L.C., and Swanson, R.A., 1991, Water resources data, Nevada, water year 1990: U.S. Geological Survey Water-Data Report NV-90-1, 358 p.

Bowen, I.S., 1926, The ratio of heat losses by conduction and by evaporation from water surfaces: Physics Review, v. 27, p. 779-787.

Bureau of Reclamation, 1967, Lake Mead area and capacity tables, 1967: Bureau of Reclamation, 127 p.

Bureau of Reclamation, 2000, Compilation of records in accordance with Article V. of the decree of the Supreme Court of the United States in Arizona v. California dated March 9, 1964, calendar year 1999: Bureau of Reclamation duplicated report, $33 \mathrm{p}$.

Clary, S.L., McClary, D.R., Whitney, Rita, and Reeves, D.D., 1995, Water resources data, Nevada, water year 1994: U.S. Geological Survey Water-Data Report NV-94-1, 768 p. 
Emett, D.C., Hutchinson, D.D., Jonson, N.A., and O'Hair, K.L., 1994, Water resources data, Nevada, water year 1993: U.S. Geological Survey Water-Data Report NV-93-1, 596 p.

Frisbie, H.R., La Camera, R.J., Riek, M.M., and Wood, D.B., 1983-85, Water resources data, Nevada, water years 198285: U.S. Geological Survey Water-Data Reports NV-82-1 to NV-85-1 (published annually).

Garcia, K.T., Gortsema, G.C., Pennington, R.N., and Preissler, A.M., 1992, Water resources data, Nevada, water year 1991: U.S. Geological Survey Water-Data Report NV-91-1, 481 p.

Harbeck, G.E., Jr., 1958a, Mass-transfer studies: Water-loss investigations, Lake Mead studies, U.S. Geological Survey Professional Paper 298, p. 29-35.

Harbeck, G.E., Jr., 1958b, Results of energy-budget and masstransfer computations: Water-Loss Investigations, Lake Mead Studies, U.S. Geological Survey Professional Paper 298, p. 35-38.

Hendricks, E.L., 1964, Compilation of records of surface waters of the United States, October 1950 to September 1960, part 9, Colorado River Basin: U.S. Geological Survey Water Supply Paper 1733, 586 p.

Hess, D.L., Mello, K.A., Sexton, R.J., and Young, R.L., 1993, Water resources data, Nevada, water year 1992: U.S. Geological Survey Water-Data Report NV-92-1, 511 p.

Jones, C.Z., Rowe, T.G., Sexton, R.J., and Tanko, D.J., 2000, Water resources data, Nevada, water year 1999: U.S. Geological Survey Water-Data Report NV-99-1, 600 p.

LaBounty, J.F., and Horn, M.J., 1997, The influence of drainage from the Las Vegas Valley on the limnology of Boulder Basin, Lake Mead, Arizona-Nevada: Journal of Lake and Reservoir Management, v. 13, no. 2, p. 95-108.

Laczniak, R.J., DeMeo, G.A., Reiner, S.R., Smith, J.L., and Nylund, W.E., 1999, Estimates of ground-water discharge as determined from measurements of evapotranspiration, Ash Meadows area, Nye County, Nevada: U.S. Geological Survey Water-Resources Investigations Report 99-4079, $70 \mathrm{p}$.

Pupacko, Alex, La Camera, R.J., Riek, M.M., and Wood, D.B., 1988, Water resources data, Nevada, water year 1986: U.S. Geological Survey Water-Data Report NV-86-1, 263 p.

Pupacko, Alex, La Camera, R.J., Riek, M.M., and Swartwood J.R., 1989a, Water-resources data, Nevada, water year 1987: U.S. Geological Survey Water-Data Report NV-87-1, 250 p.

Pupacko, Alex, La Camera, R.J., Riek, M.M., and Swartwood J.R., 1989b, Water-resources data, Nevada, water year 1988: U.S. Geological Survey Water-Data Report NV-88-1, 265 p.
Pupacko, Alex, Van Gordon, L.C., Swartwood, J.R., and Collins, R.P., 1990, Water-resources data, Nevada, water year 1989: U.S. Geological Survey Water-Data Report NV-89-1, 332 p.

Rosenberry, D.O., Sturrock, A.M., and Winter, T.C., 1993, Evaluation of the energy budget method of determining evaporation at Williams Lake, Minnesota, using alternative instrumentation and study approaches: Water Resources Research, v. 29, no. 8, p. 2473-2483.

Stanley, J.W., 1960, Reservoir storage: Comprehensive Survey of Sedimentation in Lake Mead, 1948-49: U.S. Geological Survey Professional Paper 295, p. 83-93.

Sturrock, A.M., and Rosenberry, D.O., 1992, Energy budget evaporation from Williams Lake: a closed lake in north central Minnesota: Water Resources Research, v. 28, no. 6, p. 1605-1617.

Swancar, Amy, Lee, T.M., and O'Hare, T.M., 2000, Hydrogeologic setting, water budget, and preliminary analysis of ground-water exchange at Lake Starr, a seepage lake in Polk County, Florida: U.S. Geological Survey WaterResources Investigations Report 00-4030, 66 p.

Tadayon, S., Duet, N.R., Fisk, G.G., McCormack, H.F., Partin, C.K., Pope, G.L., and Rigas, P.D., 2000, Water resources data, Arizona, water year 1999: U.S. Geological Survey Water-Data Report AZ-99-1, 370 p.

Tadayon, Saeid, Duet, N.R., Fisk, G.G., McCormack, H.F., Partin, C.K., Pope, G.L., and Rigas, P.D., 2001, Water resources data, Arizona, water year 2000: U.S. Geological Survey Water-Data Report AZ-00-1, 390 p.

U.S. Geological Survey, 1961-64, Surface water records of Nevada: U.S. Geological Survey Water-Data Report (published annually).

U.S. Geological Survey, 1965-75, Water resources for Nevada, Part 1. Survey water records, Part 2. Water quality records: U.S. Geological Water Data Report (published annually).

U.S. Geological Survey, 1976-82, Water resources data for Nevada, water years 1975-81: U.S. Geological Survey Water-Data Reports NV-75-1 to NV-81-1 (published annually).

Winter, T.C., 1981, Uncertainties in estimating the water balance of lakes: Water Resources Bulletin, v. 17, no. 1, p. 82-115. 
Evaporation from Lake Mead, Arizona and Nevada, 1997-99

This page left blank intentionally. 
For more information concerning the research in this report, contact the Director, Nevada Water Science Center

U.S. Geological Survey, 2730 N. Deer Run Road

Carson City, Nevada 89701

http://nv.water.usgs.gov 
